Perspective

\title{
Linking plant phenology to conservation biology
}

Leonor Patrícia Cerdeira Morellato ${ }^{\mathrm{a}, *}$, Bruna Alberton ${ }^{\mathrm{a}, \mathrm{b}}$, Swanni T. Alvarado ${ }^{\mathrm{c}}$, Bruno Borges ${ }^{\mathrm{a}, \mathrm{b}}$, Elise Buisson ${ }^{\mathrm{d}}$, Maria Gabriela G. Camargo a , Leonardo F. Cancian ${ }^{\text {a }}$, Daniel W. Carstensen ${ }^{\text {a }}$, Diego F.E. Escobar ${ }^{\text {a,e }}$, Patrícia T.P. Leite ${ }^{\mathrm{a}, \mathrm{e}}$, Irene Mendoza ${ }^{\mathrm{a}}$, Nathália M.W.B. Rocha ${ }^{\mathrm{a}}$, Natalia C. Soares ${ }^{\mathrm{a}, \mathrm{e}}$, Thiago Sanna Freire Silva ${ }^{\mathrm{c}}$, Vanessa G. Staggemeier ${ }^{a}$, Annia Susin Streher ${ }^{\text {b,c }}$, Betânia C. Vargas ${ }^{\text {a,e }}$, Carlos A. Peres ${ }^{f}$

${ }^{a}$ Instituto de Biociências, UNESP - Univ Estadual Paulista, Departamento de Botânica, Laboratório de Fenologia, Rio Claro, São Paulo, Brazil

b Programa de Pós-graduação em Ecologia e Biodiversidade, UNESP - Univ Estadual Paulista, Rio Claro, São Paulo, Brazil

c Instituto de Geociências e Ciências Exatas, UNESP - Univ Estadual Paulista, Departamento de Geografia, Ecosystem Dynamics Observatory, Rio Claro, São Paulo, Brazil

' Université d'Avignon et des Pays de Vaucluse, IMBE, CNRS, IRD, Aix Marseille Université, Avignon, France

e Programa de Pós-graduação em Biologia Vegetal, UNESP - Univ Estadual Paulista, Rio Claro, São Paulo, Brazil

f School of Environmental Sciences, University of East Anglia, Norwich NR4 7T], United Kingdom

\section{A R T I C L E I N F O}

\section{Article history:}

Received 8 May 2015

Received in revised form 19 December 2015

Accepted 23 December 2015

Available online 12 January 2016

\section{Keywords:}

Plant-animal interactions

Restoration ecology

Climate change

Monitoring

Management

Resource availability

\begin{abstract}
A B S T R A C T
Phenology has achieved a prominent position in current scenarios of global change research given its role in monitoring and predicting the timing of recurrent life cycle events. However, the implications of phenology to environmental conservation and management remain poorly explored. Here, we present the first explicit appraisal of how phenology - a multidisciplinary science encompassing biometeorology, ecology, and evolutionary biology can make a key contribution to contemporary conservation biology. We focus on shifts in plant phenology induced by global change, their impacts on species diversity and plant-animal interactions in the tropics, and how conservation efforts could be enhanced in relation to plant resource organization. We identify the effects of phenological changes and mismatches in the maintenance and conservation of mutualistic interactions, and examine how phenological research can contribute to evaluate, manage and mitigate the consequences of land-use change and other natural and anthropogenic disturbances, such as fire, exotic and invasive species. We also identify cutting-edge tools that can improve the spatial and temporal coverage of phenological monitoring, from satellites to drones and digital cameras. We highlight the role of historical information in recovering long-term phenological time series, and track climate-related shifts in tropical systems. Finally, we propose a set of measures to boost the contribution of phenology to conservation science. We advocate the inclusion of phenology into predictive models integrating evolutionary history to identify species groups that are either resilient or sensitive to future climate-change scenarios, and understand how phenological mismatches can affect community dynamics, ecosystem services, and conservation over time.
\end{abstract}

(c) 2015 Elsevier Ltd. All rights reserved.

\section{Contents}

1. Introduction $\ldots \ldots \ldots \ldots \ldots$

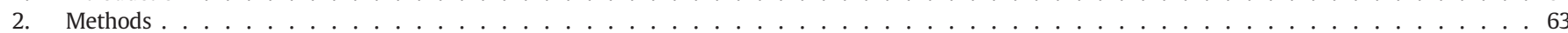

3. Phenology and the conservation of biotic interactions. . . . . . . . . . . . . . . . . . . . . . . $\ldots 3$

3.1. Leafing and herbivory. . . . . . . . . . . . . . . . . . . . . . . . . . . . . . 63

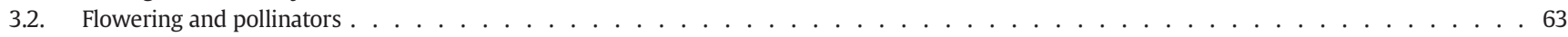

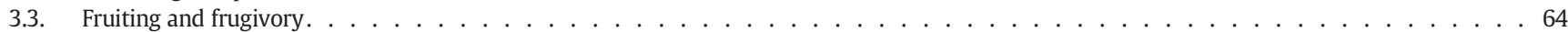

3.4. Mismatches in mutualistic networks . . . . . . . . . . . . . . . . . . . . . . . . . . . . . 64

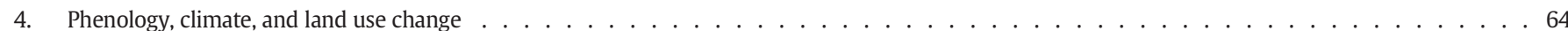

\footnotetext{
* Corresponding author at: Laboratório de Fenologia, Departamento de Botânica, Instituto de Biociências, UNESP - Univ Estadual Paulista, 13506-900 Rio Claro, São Paulo, Brazil.

E-mail addresses: pmorella@rc.unesp.br (L.P.C. Morellato), brualberton@hotmail.com (B. Alberton), swanni_ta@yahoo.es (S.T. Alvarado), bruno_borges01@hotmail.com (B. Borges), elise.buisson@univ-avignon.fr (E. Buisson), camargomgg@gmail.com (M.G.G. Camargo), lfcancian@gmail.com (L.F. Cancian), daniel.carstensen@gmail.com (D.W.Carstensen), barescoesco@gmail.com (D.F.E. Escobar), paty_zig@yahoo.com.br (P.T.P. Leite), irene.mendoza.sagrera@gmail.com (I. Mendoza), nathymwbr@gmail.com (N.M.W.B. Rocha), naturalsoares@yahoo.com.br (N.C. Soares), tsfsilva@rc.unesp.br (T.S.F. Silva), v.staggemeier@gmail.com (V.G. Staggemeier), annia.streher@gmail.com (A.S. Streher), betaniacunha@yahoo.com.br (B.C. Vargas), c.peres@uea.ac.uk (C.A. Peres).
} 


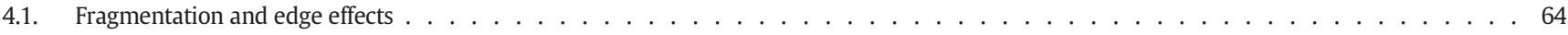

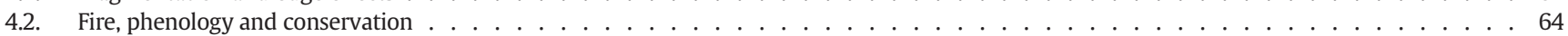

4.3. Phenological patterns and exotic, invasive and native species interactions . . . . . . . . . . . . . . . . . . . . . 65

5. Evolutionary history, species distributions and phenological variability. . . . . . . . . . . . . . . . . . . . . . . . . 65

5.1. Evolutionary history, phenology and conservation. . . . . . . . . . . . . . . . . . . . . . . . . 65

5.2. Variation within populations: why preserve individual variability. . . . . . . . . . . . . . . . . . . . . 65

6. Phenology databases, new monitoring tools and conservation practices . . . . . . . . . . . . . . . . . . . . . 66

6.1. Long-term phenological databases . . . . . . . . . . . . . . . . . . . . . . . . . . . . . . 66

6.2. Phenological monitoring and new tools . . . . . . . . . . . . . . . . . . . . . . . . . . . . . . 66

7. Conclusions: promising avenues for future research linking phenology and conservation . . . . . . . . . . . . . . . . . . . . . . . . . 69

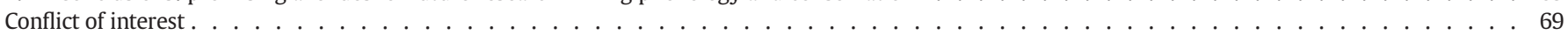

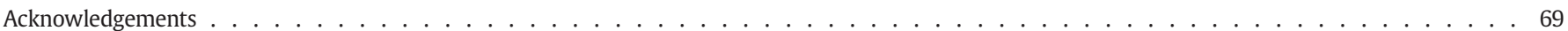

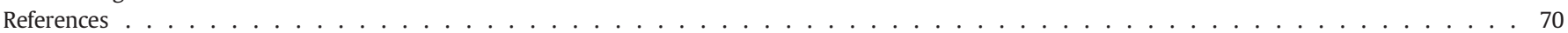

\section{Introduction}

Phenology is an integrative environmental science that has achieved a prominent position in current global-change research, due to its capacity to monitor, understand and predict the timing of recurrent biological events related to climate, such as bird migration, frog calling, and leafing, flowering and fruiting of plant populations (Rosenzweig et al., 2008). Phenological studies also provide key knowledge that can be incorporated into predictive models forecasting climate change scenarios (IPCC, 2014; Rosemartin et al., 2014).

Climate is the main factor controlling and regulating phenological events in plants, and global warming has affected species distributions and the timing of leaf change and reproduction (Chuine and Beaubien, 2001; Menzel et al., 2006), with likely effects on biogeochemical processes and physical properties of the atmosphere (van der Sleen et al., 2015). Across the tropics, subtle changes in temperature have been regarded as a less important phenological trigger, whereas seasonal variation in rainfall has been usually considered as an environmental cue for phenology (Borchert, 1998; Morellato et al., 2000, 2013). However, plant phenology responses to invariant cues, such as photoperiod, may be important in defining the timing, periodicity and particularly the synchrony of plant reproduction, especially in tropical environments where climatic seasonality is low (Borchert et al., 2005; Rivera and Borchert, 2001). Long-term phenological time series from the Northern Hemisphere have shown a strong link between the earlier onset of leafing and flowering and elevated temperatures due to climate change (Menzel et al., 2006; Schwartz et al., 2006). However, information on the effects of climate change in tropical regions is still sparse, particularly in the Southern Hemisphere, and long-term data sets are rare (Chambers et al., 2013; Morellato et al., 2013).

The management and conservation of natural systems can be critically enhanced with a greater understanding of the triggers regulating and controlling plant cycles and differences across species, populations and communities (Miller-Rushing and Weltzin, 2009; Polgar and Primack, 2011). In this regard, recent improvements in vegetation monitoring techniques such as repeated digital photographs, and the growing field of satellite-derived phenology (Alberton et al., 2014; Morisette et al., 2009; Richardson et al., 2013) have paved the way to inferences about temporal shifts at multiple scales that can be applied worldwide.

Despite the well-known connection between phenology and climate change (IPCC, 2014), its relevance and implications for resource conservation and management remain poorly understood. These implications include the synchronicity between flowering and pollinator activity or fruiting and seed disperser activity, the connectivity and gene flow through pollen and seed movements across fragmented landscapes, and the forecasting of climate-change effects on species distributions and ecosystem processes. In fact, plant phenology links different hierarchical levels and functional groups within a community, including decomposers, detritivores, herbivores, predators, pollinators, and seed dispersers. Consequently, efforts to conserve these temporal links will safeguard the functionalities and long-term maintenance of ecosystem services. In this context, we explore how phenology - as a multidisciplinary science encompassing biometeorology, ecology, and evolutionary biology (Wolkovich et al., 2014) - can be harnessed as a key research endeavour in applied ecology and conservation biology, with special emphasis on the tropics.

Our framework is centred on the potential shifts in plant phenology driven by global environmental change and their impact on the high diversity of species and plant-animal interactions found in the tropics (Fig. 1). One key issue would be to incorporate phenology into community-level coexistence theory tied to the species niche concept. As such, broadening the ecological niche to a more explicit temporal space would allow investigators to test hypotheses and make predictions regarding plant responses to environmental and competitive changes at different scales (e.g. Schellhorn et al., 2015; Wolkovich and Cleland, 2011; Wolkovich et al., 2014). We highlight issues where phenology can provide a major contribution to conservation science. We begin addressing how phenology can help conservation efforts in relation to plant-animal interactions from the perspective of resource availability in plant populations and communities, and bottom-up trophic organization. We point out the relevance of ecological networks to understand the effects of temporal changes and mismatches between resources and consumers on the maintenance of mutualistic interactions (Fig. 1). We examine how phenological mismatches affect communities, ecosystem services, and ecosystem recovery dynamics over time. Furthermore, we discuss how knowledge of plant phenology can help evaluate and mitigate the effects of landuse change on ecological interactions, including habitat fragmentation, edge effects, and fire. We also consider the thorny problem of exotic and invasive species and the key role of phenology in managing biological invasions and restoring natural ecosystem integrity. We indicate the use of phenology as a functional trait that, combined with traditional leaf morphology and other traits, would be a more accurate indicator of plant functions related to responses to climate and other environmental cues, such as wildfires (Carvalho and Batalha, 2013) or biological invasions (Wolkovich and Cleland, 2011).

To our knowledge, this is the first appraisal specifically addressing the implications of phenological knowledge to conservation biology. We propose, therefore, a set of avenues that would allow a stronger and more effective contribution of organismal phenology to conservation science. We point out the value of novel monitoring strategies improving spatial and temporal coverage of phenological monitoring, from satellites to drones and digital cameras. We highlight the key role of retrieving historical information from herbaria and observational studies to fill the gaps of long-term time series (e.g. Hart et al., 2014; Primack et al., 2004; Primack, 2014) and shed light on the potential effects of climate change and the consequences of directional phenological shifts in tropical systems. In this sense, the concept of "phenospecies" (i.e. sympatric species that share the same phenological triggers and strategies (Proença et al., 2012), may help reconstruct longer 
A)

Recurrent plant phenological events

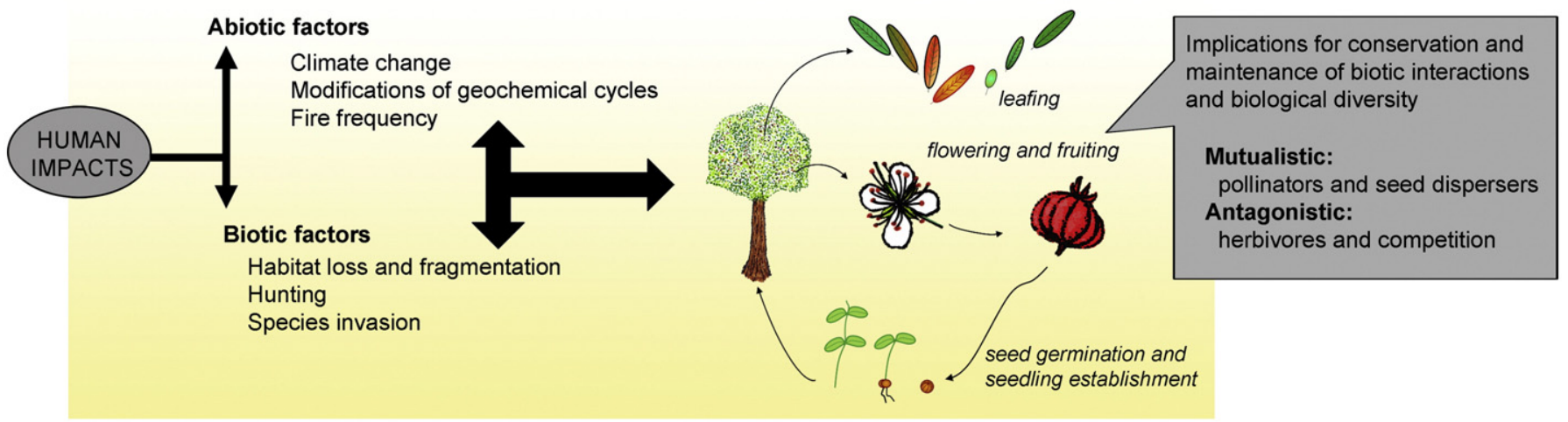

B)

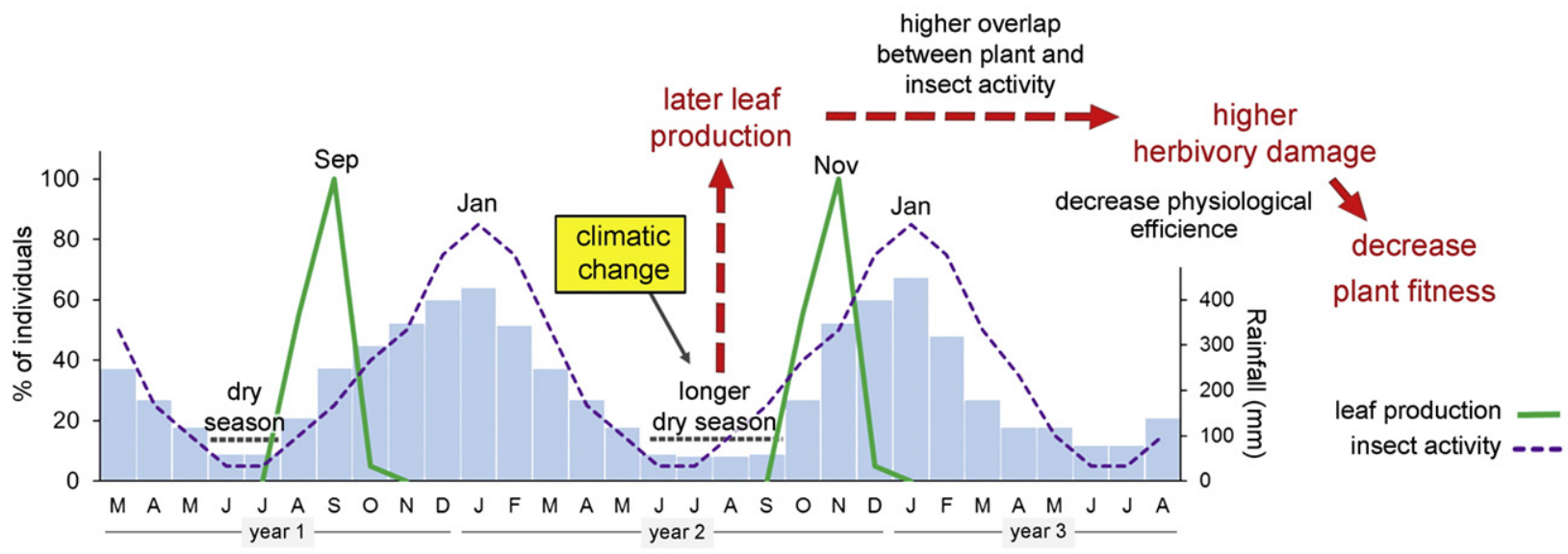

C)

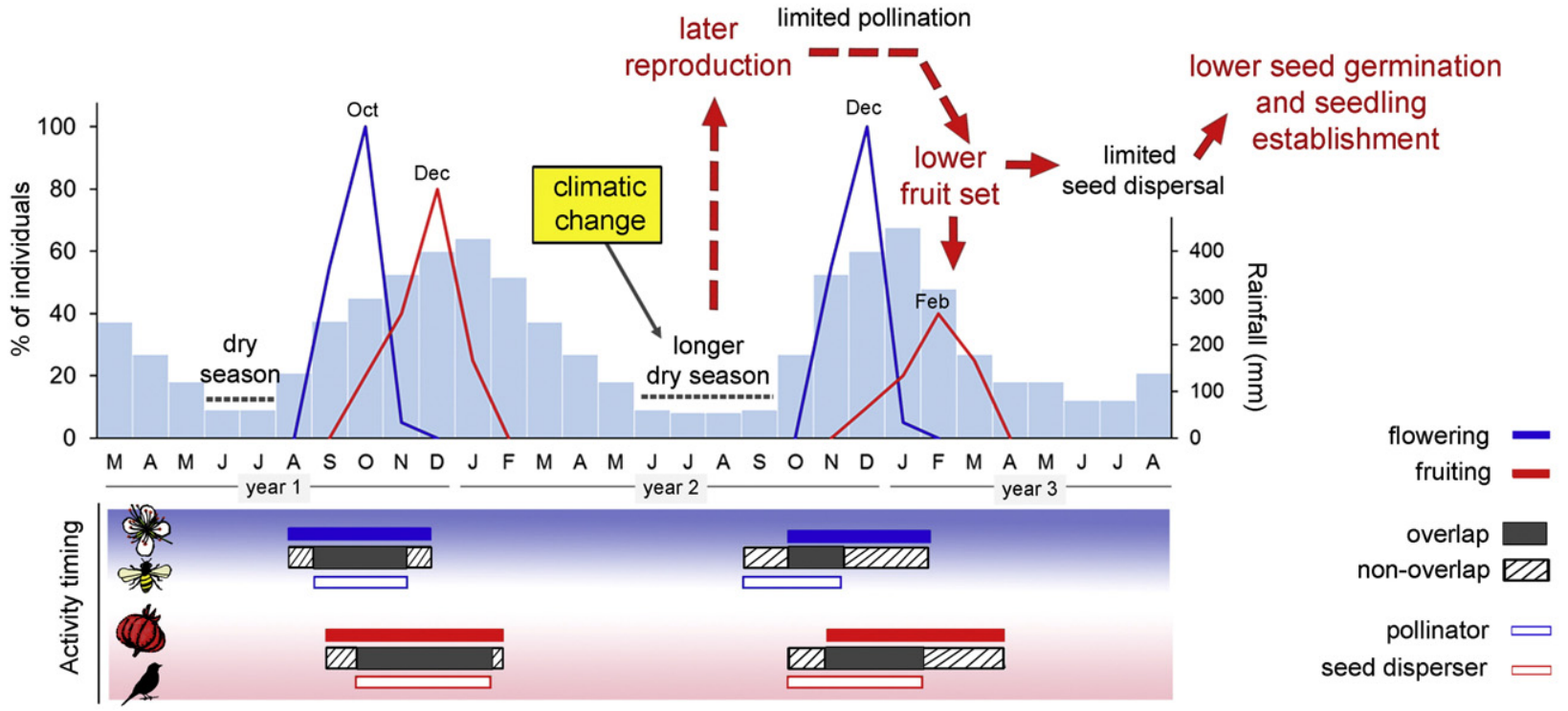

Fig. 1. Schematic diagrams exemplifying multiples hypothetical outcomes of human-induced shifts in plant phenology with implications for conservation. Human induced changes on abiotic and biotic factors affect the timing of plant and animal reproductive cycles and mutualistic interactions (A), ultimately with consequences for the conservation of biological diversity. For example, dry seasons that are either longer or more severe than usual (in this hypothetical case from 2 to 4 months) affecting the timing of leafing (B) and reproduction (C), if the trigger for leafing or flowering are the first rains at the end of dry season (e.g. Frankie et al., 1974). In this context, species producing leaves immediately after the first rains would delay leafing activity, thus overlapping with peak insect abundance (B) and, therefore, increasing herbivory damage, potentially affecting plant fitness (Aide, 1988, 1993). Flowering delays may result in a reduced overlap between plant flowering and pollinator activity (C). This plant-pollinator mismatch affects plant reproductive success (Hoye et al., 2013; Kudo and Ida, 2013; Memmott et al., 2007; Petanidou et al., 2014), and fruit production, with consequences on resource availability for frugivores, which may result in famine or death (Wright et al., 1999). Low fruit set affects the rates of seed dispersal and plant recruitment, which also occurs later in the wet season (C) (e.g. Kudo and Ida, 2013). The hypothetical schemes (A) and (B) can be read at both the species and community levels and considering other potential consequences of climate changes and phenological responses. For example, dry season severity leads to a community level earlier flowering, reducing pollination services. 
temporal series which can be investigated for biases in reproductive schedules over time. Along this line, advances in dendrochronology may also open new directions for tropical forest conservation from the point of view of past chronological reconstruction, carbon stock accumulation, and ecosystem processes (Schöngart et al., 2011). We propose integrating phenology and species evolutionary history into predictive models, to distinguish between species groups that are either resilient or sensitive to projected climate changes scenarios (Staggemeier et al., 2015; Willis et al., 2008). Finally, we draw attention to the value of citizen science to build phenology databases for conservation (Rosemartin et al., 2014; Theobald et al., 2015) and its unexplored potential in the tropics.

\section{Methods}

The present appraisal focuses on phenology from an ecological and evolutionary point of view, its relevance for climate change research and its implications and applications in conservation science, with special attention to the tropics. Our intended audience are conservation practitioners and researchers on phenology and related fields, and we strived to attain a broad but concise perspective of phenology within conservation practices. This appraisal is derived from a two-day workshop on phenology and conservation held by the Phenology Laboratory (UNESP, Brazil) in December 2014. We discussed a wide range of links between phenology to conservation science, and selected key topics with relevant contributions for the conservation and management of natural systems: phenology and conservation of biotic interactions; phenology, climate and land use change; phenology, evolutionary history and species distributions; data sets and monitoring systems; a set of practical and innovative research approaches; and new avenues for future research. The synopsis was also based on recently published (Hagen et al., 2012; Morellato et al., 2013, Chambers et al., 2013) and ongoing reviews (Buisson et al., 2015; Mendoza et al., 2014; Morellato et al., 2014) conducted by members and collaborators of the UNESP Phenology Lab, and the authors' own experience in phenology and conservation science. The criteria for the systematic literature search are available in Chambers et al. (2013) and Morellato et al. (2013). We updated these surveys by searching the top conservation science journals using the terms "phenolog*" and "conservation" over the last 10 years. Our goal was to identify relevant research and applications for conservationists and managers, rather than perform an exhaustive review of the topic.

\section{Phenology and the conservation of biotic interactions}

\subsection{Leafing and herbivory}

Studies of leafing phenology have twofold implications for conservation. First, leaf phenology is directly linked to ecosystem processes (Polgar and Primack, 2011). Leaf flushing and senescence are related to plant growth, and as such are crucial for understanding plantwater relations and primary productivity in terrestrial ecosystems, as well as gas exchange rates, biogeochemical cycling, and the dynamics of carbon sequestration (Morisette et al., 2009; Polgar and Primack, 2011). Investigating the timing and drivers of leaf production and senescence is important to define the length of growing seasons and seasonal patterns of photosynthesis at local to global scales (Morisette et al., 2009). Leaf phenology thus provides key information for ecosystem process models that forecast responses to land-use change, atmospheric chemistry, and climate (Morisette et al., 2009). Thus, shifts at both the onset and end of growing seasons due to climate change may have consequences on ecosystems processes such as net primary production. For instance, increases in temperature and drought frequency may lead to premature leaf senescence in deciduous forests, affecting the efficiency of nutrient resorption and the length of growing seasons, impacting carbon uptake and ecosystem nutrient cycling (Estiarte \&
Peñuelas 2015), and therefore management practices (e.g. Eriksson et al., 2015).

Second, the timing of leaf production has consequences for interactions between plants and herbivores (Fig. 1B), which in the tropics comprise mainly phytophagous insects (Novotny et al., 2006). The conservation of insect populations can be severely affected by changes in the timing of leaf production (Kocsis and Hufnagel, 2011), particularly in the context of declining invertebrate faunas, estimated at a global scale to have exceeded 45\% between 1970 and 2010 (Dirzo et al., 2014). In turn, shifts in herbivorous insect phenology due to climate change, land-use change, or use of insecticides can threaten plant population viability, leading to increases in herbivore damage (van Asch and Visser, 2007).

Plants can adopt several phenological strategies to avoid insect damage, such as synchronizing the timing of leafing peaks to the season with the lowest insect densities, or producing large, synchronous pulses of leaves to satiate herbivores (Aide, 1988; Lamarre et al., 2014). Future climatic scenarios may induce higher overlap between insects and plants activity (Fig. 1B), such as prolonged dry seasons delaying leaf production in plants that are stimulated by the first rains, increasing herbivore damage (Aide, 1993). Conversely, changes in abiotic factors can also reduce leafing synchrony, which would fail to satiate insect herbivores. Such extreme changes can lead to pest outbreaks and massive losses in plant production (van Asch and Visser, 2007). Phenological mismatches between agricultural pest insects and their natural enemies due to climate change could also decrease the effectiveness of biocontrol measures (Thomson et al., 2010).

Potential trophic mismatches may also arise between vertebrates and plant growing seasons, for instance as documented for caribou in Greenland where a reduction in the spatial variation in plant phenology caused by climate warming decreased offspring production (Post et al., 2008), with implications for managers and conservationists. A detailed knowledge of phenological dynamics of folivorous animals and their host/target plants can therefore be instrumental in the conservation and management of both herbivores and plant populations, and when designing pest control programmes in natural and agricultural ecosystems (Baumgartner and Hartmann, 2000; Eriksson et al., 2015).

\subsection{Flowering and pollinators}

The clearly delimited flowering seasonality during springtime, typical of temperate and boreal ecosystems, is generally absent in the tropics. Instead, open flowers are available throughout the year, albeit with varying abundances, inducing periods of peaks and troughs depending on community characteristics, and leading to diverse and complex phenological patterns (Morellato et al., 2013; Morellato et al., 2000).

Most of the world's plants rely on animal pollination for successful reproduction, especially in the tropics, where the proportion of animal-pollinated species has been estimated at 94\% (Ollerton et al., 2011). Floral resources, provided primarily as food rewards for pollination services, can also include substances used for nest construction or aromatic compounds to attract females. The reliable and continuous availability of floral resources in the tropics has enabled strong and diverse adaptations in flower visitors, maintaining rich assemblages of highly specialized floral foragers, such as bees and hummingbirds. Resource extraction by flower visitors is limited to a subset of plants, being constrained by morphology, phenology, and the behaviour of visitors (Rosas-Guerrero et al., 2014). Therefore, spatial and temporal variation in floral resource diversity, abundance and distribution are major structuring factors in pollinator communities (Burkle and Alarcon, 2011; Carstensen et al., 2014; Olesen et al., 2008).

Pollinators offer essential pollination services and play a key role in the maintenance of agricultural systems worldwide (Garibaldi et al., 2013), and the interdependency of plant and pollinator populations affects community stability and the productivity of native and agricultural systems (Vázquez et al., 2009). Flowering phenology is therefore highly 
relevant for the organization and structure of plant communities, the conservation of mutualists and their interactions, and maintenance of essential ecosystem services (CaraDonna et al., 2014; Cruz-Neto et al., 2011; Garibaldi et al., 2013).

\subsection{Fruiting and frugivory}

Frugivorous animals critically rely on fruits, and fundamental aspects of their ecology - including diet, population size, social behaviour, reproduction, and movements - depend on fruit abundance and seasonality (Hanya and Chapman, 2013), which in turn affect seed dispersal and germination effectiveness (Schupp et al., 2010). Neotropical plant species not only bear a high percentage of fruits dispersed by animals, but most tropical vertebrates are frugivores to at least some extent (Hawes and Peres, 2014). Therefore, frugivores can be constrained by low fruit production or changes in fruit supply over time (Fig. 1c) according to their nutritional content, morphology and colour (Camargo et al., 2013; Develey and Peres, 2000; Herrera, 2009), with consequences for their conservation and management (Kannan and James, 1999). Significant and unexpected crashes in fruit availability can have dramatic effects on vertebrate frugivores. For example, episodic community-wide fruit shortages following an El Niño event greatly elevated mortality of frugivorous and granivorous vertebrates in Barro Colorado Island, Panama (Wright et al., 1999).

Plant conservation is also constrained by growing defaunation scenarios in tropical ecosystems, with cascading consequences for seed dispersal and seedling establishment (Galetti and Dirzo, 2013). This is especially critical for large-seeded plant species, given their reliance on large-bodied seed dispersers that are usually the preferred targets of game hunters (Dirzo et al., 2014; Jerozolimski and Peres, 2003). For instance, defaunation of large-gaped frugivorous birds has been singled out as the main cause of rapid evolutionary change in palm seed size (Galetti et al., 2013). Though poorly studied, the same evolutionary pressure could affect plant phenology (e.g. favouring a greater overlap between fruiting and the activity of non-hunted frugivores), with farreaching consequences. Conservation of tropical communities requires an understanding of the interconnection between seasonal fluctuations in climate and the availability of resources for primary consumers (e.g. (Wright and Calderon, 2006; Wright et al., 1999), including potential changes induced by both natural (Haugaasen and Peres, 2007) and anthropogenic disturbances (Barlow and Peres, 2006; Haugaasen and Peres, 2007).

\subsection{Mismatches in mutualistic networks}

The impact of global change on plant phenology is not expected to be uniform across all species, and effects at the species level may lead to consequences at the community level, potentially changing the timing of flowering or fruiting peaks and the duration of reproductive seasons (Donnelly et al., 2011; Hanya and Chapman, 2013; Hoye et al., 2013). Furthermore, phenological change in some plant species can potentially affect other plants through competition and/or facilitation for pollinators and seed dispersers, resulting in complex community-wide responses (Burkle and Alarcon, 2011). Understanding the higherorder effects of phenological shifts on biotic interactions requires a community level approach, possibly achieved by the application of ecological networks.

Phenology is an important structuring force in plant-animal interactions and influences the topological position of species within mutualistic networks, affecting the organization of interactions and competitive relationships depending on the length and interspecific overlap of reproductive seasons (Encinas-Viso et al., 2012; Olesen et al., 2008, see Fig. 1). The length of reproductive seasons is a defining factor in the number of interaction partners a species can have. Some studies indicate that phenology plays a key role in the stability and diversity of mutualistic communities (Thébault and Fontaine, 2010) and is of key importance for the management and conservation of plant-pollination interactions and mutualistic networks (Memmott et al., 2007).

In this context, one potential threat from climate change is the temporal uncoupling of mutualistic species interactions (Hegland et al., 2009; Hoye et al., 2013; Memmott et al., 2007). Mismatches between organism and resources, such as plants and their animal symbionts, may arise if climate change affects the onset, peak, and/or duration of flowering and fruiting differentially (Fig. 1C), compared to the activity and life cycles of consumers (Donnelly et al., 2011). Such mismatch can have stark consequences, including recruitment failure in plants and resource scarcity, if not famines and population crashes, in consumers (Berg et al., 2010; Memmott et al., 2007; Wright and Calderon, 2006; Wright et al., 1999). Environmental changes that cause some level of mismatch between plants and pollinators can reduce pollination services (Petanidou et al., 2014) and, consequently, seed production (Satake et al., 2013), affecting the dynamics of plant and animal populations (Fig. 1C). The significance of temporal mismatches in the functioning of ecological communities is inextricably linked to the ability of pollinators and other mutualistic partners to switch their resource use according to the timing of availability. Recent studies indicate great variability in the identity of plant-pollinator interactions (Burkle and Alarcon, 2011; Carstensen et al., 2014; Dupont et al., 2009), which could mediate compositional changes driven by phenological mismatches (Kaiser-Bunbury et al., 2010). Changes in the taxonomic composition of visitors due to mismatching between plants and pollinators caused by earlier flowering can affect pollination success and seed set (Rafferty and Ives, 2012). Ultimately, both the ability of animal partners to forage on changing host plants as well as the maintenance of viable services for host plants from these mutualistic partners will influence the severity of potential effects of phenological mismatches and the conservation of mutualistic networks (Burkle et al., 2013; Memmott et al., 2007). However, evidence for climate-driven mismatches is at best difficult to obtain and still lacking for most systems (Miller-Rushing and Weltzin, 2009).

\section{Phenology, climate, and land use change}

\subsection{Fragmentation and edge effects}

One of the main outcomes of land-use change is habitat loss, which is arguably the main driver of declines in plant and animal diversity (Laurance, 2008). Habitat loss and the resulting fragmentation and edge effects produce fine-scale variation in light, temperature and humidity conditions, inducing phenological changes, with consequences to plant-animal interactions and ecological services reverberating throughout the ecosystem (Hagen et al., 2012). Different studies have reported an increase in flowering and fruiting activity in native habitats with increased sunlight, such as edges and gaps (Athayde and Morellato, 2014; Burgess et al., 2006; Camargo et al., 2011). However, in fragmented areas and those subjected to edge effects, this higher production in reproductive plant parts does not always favour the reproductive success and recruitment of native species from the original plant community (Athayde and Morellato, 2014; Christianini and Oliveira, 2013; Quesada et al., 2004). This is probably a consequence of the previously discussed temporal mismatches induced by new environmental conditions, with loss of pollinators and seed dispersers (Hagen et al., 2012). For conservation purposes, phenological studies investigating plant responses to particular environmental conditions, such as natural or anthropogenic edges and forest gaps, would help manage fragmented reserves (de Melo et al., 2006) and model vegetation responsiveness and susceptibility to similar environmental shifts expected in future global change scenarios (Breed et al., 2012; Hagen et al., 2012; Morellato et al., 2013).

\subsection{Fire, phenology and conservation}

Fire is a natural element of many tropical ecosystems around the world, and often determines vegetation physiognomy and species 
diversity (Bond and Keeley, 2005; Carvalho and Batalha, 2013). Fire disturbance can be either natural or anthropogenic, and the few studies evaluating the effects of fire on phenology have shown that, depending on the plant community, fire can stimulate flowering and fruiting (Pausas et al., 2004) and germination (e.g. Williams et al., 2005), elevate fruit production (Paritsis et al., 2006), and/or accelerate the phenological cycle by shifting the starting date of flowering/fruiting (Paritsis et al., 2006), but may also depress the availability of large-seeded fruits (Barlow and Peres, 2006). However, fires can also reduce flowering and fruiting by destroying buds, flowers and fruits, affecting species that reproduce during the fire season (Alvarado et al., 2014; Hoffmann, 1998) and/or favour invasive species (D'Antonio, 2000). Therefore, fire-induced changes in plant phenology comprise a key issue for vegetation management and conservation.

Phenology can be adopted as a functional trait to characterize plant community responses to fire (Carvalho and Batalha, 2013), and predict the dynamics of vegetation recovery or guide management practices and restoration strategies in fire-prone landscapes (Andersen et al., 2005). This has been the case of Ibity New Protected Area (NPA) in Madagascar. Phenology observations showed that high fire frequency reduce flower and fruit production of tapia woodlands (Alvarado et al., 2014), indicating the limited potential for natural regeneration of the vegetation (Alvarado et al., 2015). Phenological information has been used to improve the management actions for the Ibity NPA, and is considered as an important issue for the successful implementation of an integrated conservation strategy, targeting restoration of plant communities and reintroduction of threatened plant species.

\subsection{Phenological patterns and exotic, invasive and native species interactions}

The study of how native, exotic and invasive species (see Richardson et al., 2000 for definitions) interact could benefit from acknowledging plant phenology as a key trait influencing their interactions (Wolkovich and Cleland, 2011). Invasive species are managed because they modify the composition and functioning of native ecosystems, driving native species declines or local extinctions (Vilà et al., 2011). Closely related native and exotic species may hybridize if they have matching phenologies, inducing the loss of genetic diversity and disrupting locally adapted populations, such as rare and threatened species (Huxel, 1999; Vilà et al., 2000). They may further compete for pollinators and seed dispersers, altering fruit quantity, quality, seed dispersal and thus community structure and ecosystem functioning (Morales and Traveset, 2009; Vilà et al., 2000). Exotic species can also leaf out, bloom or produce fruits when natives are not producing alternative resources (thus filling a vacant niche), or can flower or germinate earlier than natives thus benefiting from a priority effect (Wolkovich and Cleland, 2011). Both cases (vacant niche and priority effect) affect native species conservation because management can be applied when exotics are vulnerable (e.g. fire, grazing, herbicide, Marushia et al., 2010; Wolkovich and Cleland, 2011) and natives are not. Exotics can also leaf or fruit for longer periods of time than natives, sustaining a wider niche, or exhibit greater flowering plasticity, both of which would confer advantages over natives, providing more adaptability to environmental changes with implications for management and conservation (Wolkovich and Cleland, 2011).

Native species can act as invasive if disturbances promote biomass growth; e.g. native liana hyperabundance resulting from increased temperature and $\mathrm{CO}_{2}$ availability associated with global atmospheric change (Phillips et al., 2002; Schnitzer et al., 2014). The phenology of liana-supporting trees may therefore be modified by light competition, affecting leaf, flower and fruit production (Avalos et al., 2007). Conversely, native lianas can play an essential role in providing flower resources to pollinators during periods of scarcity of flowering trees (Morellato and Leitão-Filho, 1996). Forest conservation and management in areas with high liana abundance must take into account these potential phenological effects and associated trade-offs.

\section{Evolutionary history, species distributions and phenological variability}

Deciphering the role of evolutionary history on phenological patterns is important to identify species that are sensitive or resilient to climate change scenarios. Moreover, building more realistic species distribution models based on historical information (from herbaria and/or ground-based phenology) can help to identify changes in plant responses over time and predict their future outcomes. This is especially relevant in systems where available phenological data are restricted to local scales and short time periods as tropical environments in the Southern Hemisphere (Chambers et al., 2013; Morellato et al., 2013).

\subsection{Evolutionary history, phenology and conservation}

Evolutionary history can affect phenology (Staggemeier et al., 2010, 2015), likely because the physiological pathways triggering reproduction are inherited at an evolutionary timescale (reviewed in Weinig et al., 2014). If evolutionary history matters, closely related species are expected to reproduce under the same environmental conditions; alternatively, if climate is the primary cue, species would reproduce in the most favourable period of time, regardless of their evolutionary relationships (Kochmer and Handel, 1986). Current molecular techniques allow us to explicitly examine the evolutionary patterns of species traits and test whether phenology has a strong phylogenetic signal (Staggemeier et al., 2010, 2015). Plants with conservative phenologies are more susceptible to changes in the climatic conditions triggering their reproduction (Willis et al., 2008). Hence, incorporating phenology into predictive models of evolutionary responses to climate change is crucial to identify fragile clades that are more susceptible to global change. Managers and conservationists can then target vulnerable species that do not modify their phenology according to climate, and design effective conservation strategies in light of climatic change scenarios (Miller-Rushing and Weltzin, 2009; Willis et al., 2008), especially in complex tropical ecosystems (Staggemeier et al., 2015). Conservation plans can prioritize the protection and maintenance of sensitive species by selecting sites that maximize their persistence.

The timing of reproduction critically defines plant reproductive success, and determines species dynamics, affecting dispersal and colonization rates and the geographic distribution of plants (Chuine and Beaubien, 2001). However, the relationships between phenology and species range attributes are underexplored in the literature (Chuine and Beaubien, 2001). For example, integrating phenological traits into ecological niche models would result in more representative and reliable projections of the ecology and dynamics of plants and biomes. We advocate combining occupancy records and phenological data archived in historical collections such as herbaria (Lavoie and Lachance, 2006) to investigate reproductive phenology at large geographic scales (Zalamea et al., 2011) and in species distribution modelling, to build predictions for future ecosystem alterations and formulate effective conservation strategies (Chapman et al., 2014).

\subsection{Variation within populations: why preserve individual variability}

Phenological patterns may differ between individuals of the same species, diverging from the average pattern exhibited by the population or community. Intraspecific variation in plant phenology can be related to the micro-environmental conditions where individuals are established, as well as genetic provenance (Herrera, 2009; Satake et al., 2013). This is highly relevant in the case of flowering, as it comprises the first mechanism of reproductive isolation; flowering synchrony is critical to the reproductive success of the predominantly out-crossing species in tropical ecosystems (Burgess et al., 2006).

Therefore, assessing the influence of local factors on individual phenology within populations becomes very relevant under current 
scenarios of global climate change (Diez et al., 2012). Population management and conservation are constrained by the available gene pool and plasticity, which enable species persistence by adaptation and successful reproduction under new environmental conditions. Environmental change reduces the local variability of coexisting conspecifics and hinders their adaptation to new scenarios, as shown for fruit/seed size in arborescent palms (Galetti et al., 2013). Fragmented and spatially isolated habitat patches can remain connected and ecologically functional if their populations maintain ecological interactions and gene flow among individuals across the landscape (D'Eon et al., 2002; Fahrig et al., 2011). Topographical diversity associated with phenological variability in populations of Centaurea scabiosa minimise the phenological mismatches with pollinator related to recent climate change (Hindle et al., 2015). Thus, understanding the processes that influence individual phenology and interactions within populations is critical, not only to ensure the viability of these plant populations, but also for the conservation of communities and ecosystems.

\section{Phenology databases, new monitoring tools and conservation practices}

\subsection{Long-term phenological databases}

Phenological monitoring typically falls outside the spectrum of mainstream conservation strategies, although basic phenological data extracted from traditional direct observations of plant populations have provided critical information for conservation planning, at all biodiversity levels defined by the Convention on Biological Diversity (CBD; www.cbd.int/convention/text/)): genes, species and ecosystems. For instance, datasets resulting from phenological studies can be organized as a seed collection calendar, supporting restoration efforts or ex situ genetic conservation (e.g. Packard et al., 2005). Also, those data sets make an invaluable contribution for initiatives such as the Kew's Millennium Seed Bank, aiming to harbour the germplasm of up to $25 \%$ of the world's plant diversity (Ali and Trivedi, 2011). Besides creating a seed collection calendar, the relationship between fruiting phenology and seed germination, dormancy (Garwood, 1983; Salazar et al., 2011; Yang et al., 2013), and storage behaviour (Pritchard et al., 2004) in seasonal habitats can be additional criteria for choosing species, methods for breaking dormancy, and seed preservation. Therefore, seeds dispersed at the onset of the rainy season tend to be non-dormant and desiccation-sensitive, while those dispersed during the dry season tend to be dormant and desiccation-tolerant (Salazar et al., 2011; Yang et al., 2013).

From a conservation perspective, phenological research is the basis of several studies, such as the effects of generalized fruiting failure on periodic frugivore famines (e.g. due to El Niño events, Wright et al., 1999), or the importance of the timing of fruiting peaks for breeding seasons of frugivorous birds (Develey and Peres, 2000). Also, defining keystone plants for vertebrate fauna during lean times of the year relies on previous knowledge of the phenological patterns of non-redundant resources, compared to alternative resources across the entire plant community (Peres, 2000).

Herbaria are a remarkable database and significant source of long-term phenological data that have been used to reconstruct past historical patterns of plant phenology (Hart et al., 2014; Lavoie and Lachance, 2006; Primack et al., 2004). Phenological time series from herbarium can be a reliable predictive tool in the context of scarce historical information from ground observation, especially in the tropics (Chambers et al., 2013; Morellato et al., 2013). Therefore, herbarium records can play a key contribution to conservation, providing data on reproductive patterns of single species to whole assemblages across entire regions where no phenological information is available (Bolmgren and Lonnberg, 2005; Boulter et al., 2006; Rawal et al., 2015; Tannus and Assis, 2004). Considering the growing number of digitalized collections from herbaria all around the world, including some major tropical herbaria, phenological information is available at no cost for managers and conservationists at sites such as the REFLORA, the website for the Brazilian Herbaria collections and species lists (http://reflora.jbrj.gov.br/jabot/PrincipalUC/PrincipalUC. do;jsessionid=52939BFB2B6A0EE6DAE92077C796583F). In addition, one may infer geographic patterns and build phylogeographic models that can offer key insights on the future distribution of endangered and rare species. We can further use herbarium records to identify "phenospecies" (Proença et al., 2012), which can be investigated for shifts in reproductive schedules over time (Borchert, 1998; Primack, 2014; Rivera and Borchert, 2001).

Dendrochronology has been also an effective way to reconstruct longer series of leaf phenology for understudied systems, as the growth rings and cambial activity of tree species are linked to climate (Schweingruber, 1996). Although little information is available on tree-ring analysis for tropical trees (Worbes, 2002), new methods and tools have increased the reconstruction accuracy of the periodicity of growth ring formation (Roig, 2000) and, as a consequence, the prediction of growth seasons and carbon stocks of ecosystems. Dendrochronology and phenology have been applied to understand how climatic variables influence growth and cambial activity of tree species (Brienen et al., 2010), and develop growth models that inform the management and conservation of different tree species (Lisi et al., 2008; Schöngart, 2008), including some of the most important non-timber forest products in tropical forests, such as the Brazil-nut tree (Schöngart et al., 2015), which is threatened by systematic overexploitation of mature seeds (Peres et al., 2003). Long-term observations of the cambial phenology may facilitate the interpretation of cell differentiation phases, the length of the growing season and how their growth respond to environmental changes (Rossi et al., 2012). This factor can be critical in cell production and carbon uptake by forests (Rossi et al., 2013).

\subsection{Phenological monitoring and new tools}

Phenological monitoring techniques continues to grow in tandem with the increasing importance of systematic phenological data to explain ecological patterns, predict the effects of climate change, and address applied environmental and conservation issues (Miller-Rushing and Weltzin, 2009). This has led to the development of alternative observation methods (Morisette et al., 2009), such as phenological networks (Betancourt et al., 2005; Fuccillo et al., 2014), remote sensingbased phenology from regional to global scales (Reed et al., 2013), and more recently, deployment of in situ digital cameras for continuous monitoring of multiple simultaneous sites, referred to as near-surface remote phenology (e.g., Richardson et al., 2009, 2013). Sampling species-rich plant communities can be expensive and labour-intensive in tropical phenology studies, limiting the establishment of comprehensive direct phenological observation systems, and increasing the relevance of alternative techniques such digital repeated photographs (Alberton et al., 2014).

Near-surface remote phenology using digital cameras ("phenocams") allows the daily detection of leafing events according to changes in the red, green and blue (RGB) channels (Crimmins and Crimmins, 2008; Morisette et al., 2009), and have become reliable tools in monitoring leafing changes even in highly diverse vegetation in the seasonal tropics (Alberton et al., 2014).

Orbital remote sensing provides daily to monthly observations of surface radiation, which can be associated to changes in biophysical (e.g. leaf area index) and biochemical (e.g. chlorophyll and water content) vegetation parameters, thereby tracking phenology across space and time (Reed et al., 2013). Remote sensing approaches have proved useful in detecting seasonal vegetation changes over a large range of spatial and temporal scales, and have been incorporated into conservation practices (Nagendra et al., 2013). In the National Park network of Spain, radiometric information derived from the NOAA/AVHRR sensor series was used to assess changes in 
Box 1

A brief practical guide for the integration of plant phenology into conservation science.

\begin{tabular}{|c|c|c|c|}
\hline Conservation practice & Phenological data sources & Ecological scale & Examples \\
\hline $\begin{array}{l}\text { Establishment of a calendar for } \\
\text { collection of seeds and other } \\
\text { plant resources for in situ or ex } \\
\text { situ conservation }\end{array}$ & $\begin{array}{l}\text { Direct ground observation of } \\
\text { plant phenophases (e.g. leafing, } \\
\text { flowering, fruiting) and their } \\
\text { interaction with local } \\
\text { environmental variables }\end{array}$ & Population/species & $\begin{array}{l}\text { Kew's Millennium Seed Bank } \\
\text { Project uses information on } \\
\text { fruiting, seed germination, } \\
\text { dormancy and storage for } \\
\text { appropriate ex situ conservation } \\
\text { techniques of over } 27,000 \text { plant } \\
\text { species (Ali and Trivedi, 2011) }\end{array}$ \\
\hline $\begin{array}{l}\text { Knowledge on the flower/fruit } \\
\text { production of a threatened plant } \\
\text { species to support conservation } \\
\text { strategies }\end{array}$ & $\begin{array}{l}\text { Qualitative and/or quantitative } \\
\text { estimate of flower and/or fruit } \\
\text { production over time }\end{array}$ & Population/species & $\begin{array}{l}\text { Study focused on the phenology of } \\
\text { the rare species (e.g. Horsfieldia } \\
\text { kingii) showed limited availability } \\
\text { of fruits for its main seed disperser } \\
\text { (Datta and Rane, 2013) }\end{array}$ \\
\hline $\begin{array}{l}\text { Increase of intra-population } \\
\text { diversity and gene pool }\end{array}$ & & Population/species & $\begin{array}{l}\text { Topographical variation reduced } \\
\text { chances of phenological } \\
\text { mismatches between Centaurea } \\
\text { scabiosa and its pollinator (Hindle } \\
\text { et al., 2015). }\end{array}$ \\
\hline $\begin{array}{l}\text { Maintain the resource availability in } \\
\text { time and space to preserve } \\
\text { pollination vectors and support } \\
\text { ecosystem services }\end{array}$ & $\begin{array}{l}\text { Flowering and fruiting phenology } \\
\text { at different scales }\end{array}$ & Community/population/species & $\begin{array}{l}\text { Managing natural and agricultural } \\
\text { landscapes for continuous resource } \\
\text { availability for pollinators, thereby } \\
\text { maintaining ecosystem services } \\
\text { (Schellhorn et al., 2015) }\end{array}$ \\
\hline $\begin{array}{l}\text { Control herbivory population and } \\
\text { damage, }\end{array}$ & $\begin{array}{l}\text { Leafing of host plant species and } \\
\text { phenology of phytophagous } \\
\text { insects }\end{array}$ & Population/species & $\begin{array}{l}\text { Years of high synchrony of } \\
\text { leaf-feeding Lepidoptera and leafing } \\
\text { peaks cause herbivore outbreaks. } \\
\text { Disruption of the synchrony } \\
\text { between herbivores and their host } \\
\text { plants caused by climate change } \\
\text { may affect population viability if } \\
\text { synchronicity is not restored (van } \\
\text { Asch and Visser, 2007). }\end{array}$ \\
\hline $\begin{array}{l}\text { Harvesting sustainability of } \\
\text { non-timber forest products }\end{array}$ & $\begin{array}{l}\text { Information on flowering and } \\
\text { fruiting time and fruit/seed crop } \\
\text { size }\end{array}$ & Population & $\begin{array}{l}\text { Seed and flower phenology surveys } \\
\text { over a large geographic area, } \\
\text { ethno-ecological interviews, and } \\
\text { harvest experiments to guide } \\
\text { sustainable management of the } \\
\text { Brazilian golden-grass (Syngonanthus } \\
\text { nitens - Eriocaulaceae, Schmidt } \\
\text { et al., 2007) }\end{array}$ \\
\hline $\begin{array}{l}\text { Maintenance of animal populations } \\
\text { critically depending on fruit } \\
\text { resources for survival }\end{array}$ & $\begin{array}{l}\text { Seed traps: timing and fruit/seed } \\
\text { crop size }\end{array}$ & Community & $\begin{array}{l}\text { Vertebrate frugivore famines in } \\
\text { Barro Colorado Island, Panama, as } \\
\text { consequence of abnormally low } \\
\text { fruit production associated with an } \\
\text { El Niño event (Wright et al., 1999) }\end{array}$ \\
\hline $\begin{array}{l}\text { Detection of potential keystone } \\
\text { plant species }\end{array}$ & & Community & $\begin{array}{l}\text { Data from } 8 \text { years of seed-fall } \\
\text { enabled distinguishing seven } \\
\text { keystone species that bear } \\
\text { disproportionally important } \\
\text { resources during periods of scarcity } \\
\text { at Cocha Cashu, Manu National } \\
\text { Park, Peru (Diaz-Martin et al., 2014) }\end{array}$ \\
\hline $\begin{array}{l}\text { Conservation plans considering not } \\
\text { only target species but also their } \\
\text { ecological interactions }\end{array}$ & $\begin{array}{l}\text { Phenology of plant species and } \\
\text { their mutualistic and antagonistic } \\
\text { interactions (e.g. pollinators, } \\
\text { seed dispersers, parasites) }\end{array}$ & Community & $\begin{array}{l}\text { Plant-pollinator interactions are } \\
\text { strongly determined by phenology } \\
\text { (Olesen et al., 2008) }\end{array}$ \\
\hline $\begin{array}{l}\text { Assessing impacts of climate change } \\
\text { on plant species phenology to } \\
\text { guide mitigation actions }\end{array}$ & $\begin{array}{l}\text { Long-term phenological time } \\
\text { series from herbarium collections } \\
\text { and historical records }\end{array}$ & Species & $\begin{array}{l}\text { Reconstruction of a long-term } \\
\text { phenological pattern of a } \\
\text { high-value medicinal herb of the } \\
\text { Indian Himalayan Region to under- } \\
\text { stand climate change effects (Gaira } \\
\text { et al., 2011). }\end{array}$ \\
\hline
\end{tabular}


Box 1 (continued)

\begin{tabular}{|c|c|c|c|}
\hline Conservation practice & Phenological data sources & Ecological scale & Examples \\
\hline & $\begin{array}{l}\text { Flowering and fruiting time from } \\
\text { herbarium collections }\end{array}$ & $\begin{array}{l}\text { Community, landscape and } \\
\text { ecosystem }\end{array}$ & $\begin{array}{l}\text { Accessing fruiting and flowering } \\
\text { phenology and climatic triggers at } \\
\text { large scales (Bolmgren and } \\
\text { Lonnberg, 2005; Boulter et al., } \\
\text { 2006). }\end{array}$ \\
\hline $\begin{array}{l}\text { Estimates of carbon stocks and } \\
\text { development of growth models } \\
\text { that provide baseline ground } \\
\text { information for the management } \\
\text { and conservation of different tree } \\
\text { species }\end{array}$ & $\begin{array}{l}\text { Phenology of plant growth from } \\
\text { dendrochronological approaches }\end{array}$ & $\begin{array}{l}\text { Species, landscape and } \\
\text { ecosystem }\end{array}$ & $\begin{array}{l}\text { Long-term observations of the } \\
\text { cambial phenology showed growth } \\
\text { responses to environmental } \\
\text { changes (Rossi et al., 2012). }\end{array}$ \\
\hline $\begin{array}{l}\text { Forecasting groups of plants more } \\
\text { vulnerable or resilient to climate } \\
\text { change to set effective priorities } \\
\text { for conservation agendas. }\end{array}$ & $\begin{array}{l}\text { Phenological data within a } \\
\text { phylogenetic/evolutionary } \\
\text { context }\end{array}$ & Community & $\begin{array}{l}\text { Analysing the phenology of the } \\
\text { Neotropical Myrtaceae using a } \\
\text { phylogenetical framework detected } \\
\text { the species sharing a more } \\
\text { conservative phenology, thus } \\
\text { elucidating the principal candidates } \\
\text { for conservation initiatives } \\
\text { (Staggemeier et al., 2015) }\end{array}$ \\
\hline $\begin{array}{l}\text { Identification of early colonists that } \\
\text { can facilitate the establishment of } \\
\text { latecomers by amplifying the } \\
\text { trophic resource base for } \\
\text { frugivores operating as effective } \\
\text { seed vectors }\end{array}$ & $\begin{array}{l}\text { Plant phenology across } \\
\text { successional chronosequences }\end{array}$ & Community & $\begin{array}{l}\text { Long-lived pioneers that bear } \\
\text { keystone resources (e.g. ripe fruits) } \\
\text { over extended fruiting seasons, } \\
\text { such as several neotropical } \\
\text { arborescent palms; species } \\
\text { exhibiting intra-population fruiting } \\
\text { asynchrony are instrumental in } \\
\text { sustaining a large coterie and } \\
\text { aggregate biomass of generalist } \\
\text { frugivores throughout the year } \\
\text { (Peres, 1994a, 1994b) }\end{array}$ \\
\hline $\begin{array}{l}\text { Monitoring vegetation changes to } \\
\text { detect vegetation recovery and } \\
\text { resilience to natural and } \\
\text { anthropogenic disturbances }\end{array}$ & $\begin{array}{l}\text { Near-surface remote phenology } \\
\text { using digital cameras } \\
\text { ("phenocams") }\end{array}$ & Landscape and ecosystem & $\begin{array}{l}\text { Monitoring: fire incidence and } \\
\text { resilience in fire-prone ecosystems; } \\
\text { vegetation recovery and restoration }\end{array}$ \\
\hline $\begin{array}{l}\text { Spatially explicit measurement of } \\
\text { vegetation responses to climatic } \\
\text { factors and disturbances over } \\
\text { multiple spatial and temporal } \\
\text { scales }\end{array}$ & $\begin{array}{l}\text { Remote sensing of plant } \\
\text { phenology }\end{array}$ & Ecosystem and planetary & $\begin{array}{l}\text { The US Geological Survey (USGS) } \\
\text { combines remote sensing imagery } \\
\text { with phenological field-collected } \\
\text { datasets obtained by the USA } \\
\text { National Phenology Network } \\
\text { (USA-NPN, Graham et al., 2011; } \\
\text { Willis, 2015) }\end{array}$ \\
\hline
\end{tabular}

phenological activity between 1982 and 2006, detecting a decrease in seasonality and the advancing of leaf peak activity (AlcarazSegura et al., 2009). In North America, the United States Geological Survey (USGS) is at the forefront on collaborative studies in phenology, combining remote sensing imagery with field-collected datasets obtained by the USA National Phenology Network (USA-NPN, Graham et al., 2011; Willis, 2015). The typical high temporal frequency of these sensors, although not appropriate for local scale or individuals monitoring, provides valuable phenological information for ecologists and land managers, and support decisions on the allocation of further resources for more detailed spatial assessments (Nagendra et al., 2013; Willis, 2015).

Recent developments in remote sensing, such as hyperspectral, hyperspatial, and 3-D remote sensing (LiDAR and InSAR) bring the promise of identifying individual species and directly estimating leaf and canopy traits, which will enable a better coupling with traditional phenology (Reed et al., 2013). More recently, rapid advances in unmanned aerial systems (UAS) have allowed 
the deployment of these technologies with high temporal repeatability, providing an unparalleled platform for high-resolution phenological data acquisition (Anderson and Gaston, 2013). The ability of UAS in providing centimetre spatial resolution data at low cost, and the range of sensors that can be integrated to these systems also have wide applications in conservation science (Colomina and Molina, 2014). Paneque-Gálvez et al. (2014) discuss how small drones can support continuous monitoring and aid management and environmental conservation actions, and be easily included in community-based monitoring programmes due to its low-cost and ease of operation.

The use of UAS increases monitoring capacity when quantifying land use change, enabling comprehensive ecosystem surveys and monitoring of animal populations at low cost and reduced manpower (Koh and Wich, 2012). Furthermore, the use of specific software and algorithms to extract three-dimensional data from low-cost, UAV-based aerial photography, allows the repeated monitoring of several measures related to vegetation structure and complexity, which can help conservationists to address temporal and spatial vegetation dynamics in the landscape and evaluate vegetation recovery for conservation goals (Zahawi et al., 2015).

\section{Conclusions: promising avenues for future research linking phenology and conservation}

Plant reproduction triggers remain poorly understood across the tropics, especially in highly aseasonal ecosystems (Morellato et al., 2013). Recent advances in digital technologies to retrieve historical phenological information from herbaria, satellite images and field cameras will be essential to improve our capability to define proximate triggers, and forecast the effects of climate change. That is the promise of the e-phenology Phenology Project (http://www.recod.ic.unicamp.br/ ephenology/client/index.html), the first tropical initiative to build a network of digital cameras monitoring several vegetation systems in Brazil, while integrating UAVs and remote sensing into phenology monitoring, combined with the traditional on-the-ground direct observations (Alberton et al., 2014; Morellato et al., 2014).

As previously discussed, few studies have confirmed the occurrence of phenological mismatches due to climate or land-use change, and to our knowledge, none of these studies has been conducted in tropical systems, partly because suitable data sets are scarce. Phenology can help identify resource discontinuities along the chronosequence of plant resource availability for consumers that may affect growth and reproduction of target organisms (Schellhorn et al., 2015), and the resulting mismatches in time and space. The understanding and support of ecosystem services provided by biodiversity should take into account the temporal dimension in resource abundance and dynamics across the landscape (Schellhorn et al., 2015).

We therefore propose a series of measures and research topics that can increase the contribution of phenology research to conservation science (Box 1). We have described how phenological studies can support conservation management protocols in actively triggering or accelerating the resilience of degraded ecosystems, potentially making a large contribution to the general research framework on global climate and land-use change. Phenological parameters provide essential measures that can be easily recorded and directly applied to an evolving conservation paradigm centred on preserving ecological processes, rather than a single-minded focus on endangered species or forest structure (Bennett et al., 2009). Recently, phenology was included among the Essential Biodiversity Variables (EBV), defined as "a measurement required for study, reporting, and management of biodiversity change" (GCOS, 2010; Pereira et al., 2013). The idea is achieving a global monitoring system that would provide critical data capturing chief elements of biodiversity change, thereby improving conservation management. Phenology as an EBV reaches the criteria of scalability, temporal sensitivity, feasibility, and relevance (Pereira et al., 2013). Remote sensing phenology is highlighted along with the few phenology global networks (Pereira et al., 2013). We also advocate developing other data platforms, especially citizen-science initiatives (Theobald et al., 2015), a denser network of local direct observations, and herbarium data (Lavoie and Lachance, 2006; Proença et al., 2012). Those data sources will provide invaluable information to validate remote sensing global patterns and improve biodiversity management and conservation.

The advancements in information science technologies to digitalize herbaria records and retrieve the historical phenological information from herbaria, satellite images and field cameras, will be essential to improve our capability to define proximate triggers and forecast the effects of climate change. The very essence of the importance of recovering historic phenological information, and its wide application for conservation, are illustrated by the work of Primack (2014) on the Thoreau records. As technology evolves and Land Surface Phenology becomes more likely, the ubiquity of ground-based phenology and remote sensing approaches will play an increasingly important role for phenology and conservation. This will help answer questions about the timing and drivers of phenological events under climate and land-cover change scenarios, especially in highly diverse and heterogeneous tropical system.

A final approach concerns the relevance of plant phenology as a tool for conservation education and citizen science as a whole (Fuccillo et al., 2014). Unfortunately, tropical countries have no proposed data acquisition networks or citizen science initiatives that are analogous to important phenological programmes in North America (USA - NPN https:// www.usanpn.org/and Cornell Bird Laboratory http://www.birds. cornell.edu/page.aspx?pid=1664); Canada - PlantWatch https:// www.naturewatch.ca/plantwatch/) and Europe (United Kingdom https://www.naturescalendar.org,uk) (Gonsamo et al., 2013) or the new Australian network (ClimateWatch - Australia's National Phenology Network, https://www.climatewatch.org.au). The whole of Latin America, Africa and South-East Asia lacks similar initiatives, but we consider this a worthwhile goal to pursue in the near future. Those networks will become increasingly valuable for conservation managers (Rosemartin et al., 2014) wherever they can obtain cost-effective phenological information, boosting our capacity to preserve natural resources and ecosystem services.

\section{Conflict of interest}

The authors declare no conflicts of interest.

\section{Acknowledgements}

Our research was supported by Sao Paulo Research Foundation (FAPESP) grants FAPESP-Microsoft Research \# 2013/50155-0 and \#2010/52113-5; FAPESP-VALE-FAPEMIG \# 2010/51307-0); additional funds were provided by CNPq (Conselho Nacional de Desenvolvimento Científico e Tecnológico) through grants CNPq/LBA 458038/2013-0 and CNPq PELD Cipó. LPCM holds a research productivity fellowship from CNPq. The following authors received fellowships from FAPESP: BA (grant \# 2014/00215-0); STA (grant \# 2014/12728-1); BDB (grant \# 2014/07700-0); MGGC (grant \# 2010/01762-3); LFC (grant \# 2014/ 13354-8); DWC (grants \# 2011/22635-2, \# 2014/01594-4); IM (grant \# 2012/21601-0); NMWBR (grant \# 2012/12429-9); VGS (grant \# 2014/13899-4), and ASS (grant \# 2015/17534-3). The authors DFEE, PTL, NCS, ASS and BCV received a fellowship from CAPES (Coordenação de Aperfeiçoamento de Pessoal do Ensino Superior) through the Programa de Pós-graduação em Biologia Vegetal - UNESP, Rio Claro and the Programa de Pós-graduação em Ecologia e Biodiversidade UNESP, Rio Claro. EB was supported by grants from French Embassy/ UNESP Rio Claro, Chairs 2012 and 2014, STA (grant \# 035/016/13PROPe/CDC) and MGGC (Recém-doutor \#292) received support from PROPe/CDC/UNESP; and CAP is supported by CAPES grant PVE 004/ 2012. 


\section{References}

Aide, T.M., 1988. Herbivory as a selective agent on the timing of leaf production in a tropical understory community. Nature 336, 574-575.

Aide, T.M., 1993. Patterns of leaf development and herbivory in a tropical understory community. Ecology 74, 455-466.

Alberton, B., Almeida, J., Helm, R., da Torres, S.R., Menzel, A., Morellato, L.P.C., 2014. Using phenological cameras to track the green up in a cerrado savanna and its on-theground validation. Ecol. Inform. 19, 62-70.

Alcaraz-Segura, D., Cabello, J., Paruelo, J.M., Delibes, M., 2009. Use of descriptors of ecosystem functioning for monitoring a national park network: a remote sensing approach. Environ. Manag. 43, 38-48.

Ali, N.S., Trivedi, C., 2011. Botanic gardens and climate change: a review of scientific activities at the Royal Botanic Gardens, Kew. Biodivers. Conserv. 20, 295-307.

Alvarado, S.T., Buisson, E., Carrière, S.M., Rabarison, H., Rajeriarison, C., Andrianjafy, M., Randriatsivery, F.M., Rasoafaranaivo, M.H., Raharimampionona, J., Lowry, I.I., Porter, P., Birkinshaw, C., 2015. Achieving sustainable conservation in Madagascar: the case of the newly established Ibity Mountain Protected Area. Trop. Conserv. Sci. 8 , 367-395.

Alvarado, S.T., Buisson, E., Rabarison, H., Rajeriarison, C., Birkinshaw, C., Lowry Ii, P.P., Morellato, L.P.C., 2014. Fire and the reproductive phenology of endangered Madagascar sclerophyllous tapia woodlands. S. Afr. J. Bot. 94, 79-87.

Andersen, A.N., Cook, G.D., Corbett, L.K., Douglas, M.M., Eager, R.W., Russell-Smith, J., Setterfield, S.A., Williams, R.J., Woinarski, J.C.Z., 2005. Fire frequency and biodiversity conservation in Australian tropical savannas: implications from the Kapalga fire experiment. Austral Ecol. 30, 155-167.

Anderson, K., Gaston, K.J., 2013. Lightweight unmanned aerial vehicles will revolutionize spatial ecology. Front. Ecol. Environ. 11, 138-146.

Athayde, E.A., Morellato, L.P.C., 2014. Anthropogenic edges, isolation and the flowering time and fruit set of Anadenanthera peregrina, a cerrado savanna tree. Int. J. Biometeorol. 58, 443-454.

Avalos, G., Mulkey, S.S., Kitajima, K., Wright, S.J., 2007. Colonization strategies of two liana species in a tropical dry forest canopy. Biotropica 39, 393-399.

Barlow, J., Peres, C.A., 2006. Effects of single and recurrent wildfires on fruit production and large vertebrate abundance in a central Amazonian forest. Biodivers. Conserv. $15,985-1012$

Baumgartner, J., Hartmann, J., 2000. The use of phenology models in plant conservation programmes: the establishment of the earliest cutting date for the wild daffodil Narcissus radiiflorus. Biol. Conserv. 93, 155-161.

Bennett, A.F., Haslem, A., Cheal, D.C., Clarke, M.F., Jones, R.N., Koehn, J.D., Lake, P.S., Lumsden, L.F., Lunt, I.D., Mackey, B.G., 2009. Ecological processes: a key element in strategies for nature conservation. Ecol. Manag. Restor. 10, 192-199.

Berg, M.P., Kiers, E.T., Driessen, G., van der Heijden, M., Kooi, B.W., Kuenen, F., Liefting, M., Verhoef, H.A., Ellers, J., 2010. Adapt or disperse: understanding species persistence in a changing world. Glob. Chang. Biol. 16, 587-598.

Betancourt, J.L., Schwartz, M.D., Breshears, D.D., Cayan, D.R., Dettinger, M.D., Inouye, D.W., Post, E., Reed, B.C., 2005. Implementing a US national phenology network. EOS Trans. Am. Geophys. Union 86539.

Bolmgren, K., Lonnberg, K., 2005. Herbarium data reveal an association between fleshy fruit type and earlier flowering time. Int. J. Plant Sci. 166, 663-670.

Bond, W.J., Keeley, J.E., 2005. Fire as a global 'herbivore': the ecology and evolution of flammable ecosystems. Trends Ecol. Evol. 20, 387-394.

Borchert, R., 1998. Responses of tropical trees to rainfall seasonality and its long-term changes. Clim. Chang. 39, 381-393.

Borchert, R., Renner, S.S., Calle, Z., Navarrete, D., Tye, A., Gautier, L., Spichiger, R., von Hildebrand, P., 2005. Photoperiodic induction of synchronous flowering near the Equator. Nature 433, 627-629.

Boulter, S.L., Kitching, R.L., Howlett, B.G., 2006. Family, visitors and the weather: patterns of flowering in tropical rain forests of northern Australia. J. Ecol. 94, 369-382.

Breed, M.F., Gardner, M.G., Ottewell, K.M., Navarro, C.M., Lowe, A.J., 2012. Shifts in reproductive assurance strategies and inbreeding costs associated with habitat fragmentation in Central American mahogany. Ecol. Lett. 15, 444-452.

Brienen, R.J.W., Zuidema, P.A., Martinez-Ramos, M., 2010. Attaining the canopy in dry and moist tropical forests: strong differences in tree growth trajectories reflect variation in growing conditions. Oecologia 163, 485-496.

Buisson, E., Alvarado, S.T., Le Stradic, S., Morellato, L.P.C., 2015. How can Phenology Contribute to Ecological Restoration? SER 2015. 6th World Conference on Ecological Restoration. pp. 92-93.

Burgess, V.J., Kelly, D., Robertson, A.W., Ladley, J.J., 2006. Positive effects of forest edges on plant reproduction: literature review and a case study of bee visitation to flowers of Peraxilla tetrapetala (Loranthaceae). N. Z. J. Ecol. 30, 179-190.

Burkle, L.A., Alarcon, R., 2011. The future of plant-pollinator diversity: understanding interaction networks across time, space, and global change. Am. J. Bot. 98, 528-538.

Burkle, L.A., Marlin, J.C., Knight, T.M., 2013. Plant-pollinator interactions over 120 years: loss of species, co-occurrence, and function. Science 339, 1611-1615.

Camargo, M.G.G., Cazetta, E., Schaefer, H.M., Morellato, L.P.C., 2013. Fruit color and contrast in seasonal habitats - a case study from a cerrado savanna. Oikos 122 , $1335-1342$.

Camargo, M.G.G., Souza, R.M., Reys, P., Morellato, L.P.C., 2011. Effects of environmental conditions associated to the cardinal orientation on the reproductive phenology of the cerrado savanna tree Xylopia aromatica (Annonaceae). An. Acad. Bras. Cienc. 83, 1007-1019.

CaraDonna, P.J., Iler, A.M., Inouye, D.W., 2014. Shifts in flowering phenology reshape a subalpine plant community. Proc. Natl. Acad. Sci. 111, 4916-4921.
Carstensen, D.W., Sabatino, M., Trøjelsgaard, K., Morellato, L.P.C., 2014. Beta diversity of plant-pollinator networks and the spatial turnover of pairwise interactions. PLoS One 9, e112903.

Carvalho, G.H., Batalha, M.A., 2013. The drivers of woody species richness and density in a Neotropical savannah. Biol. Lett. 9, 20130412.

Chambers, L.E., Altwegg, R., Barbraud, C., Barnard, P., Beaumont, L.J., Crawford, R.J.M., Durant, J.M., Hughes, L., Keatley, M.R., Low, M., Morellato, P.C., Poloczanska, E.S. Ruoppolo, V., Vanstreels, R.E.T., Woehler, E.J., Wolfaardt, A.C., 2013. Phenological changes in the southern hemisphere. PLoS One 8.

Chapman, D.S., Haynes, T., Beal, S., Essl, F., Bullock, J.M., 2014. Phenology predicts the native and invasive range limits of common ragweed. Glob. Chang. Biol. 20, 192-202.

Christianini, A.V., Oliveira, P.S., 2013. Edge effects decrease ant-derived benefits to seedlings in a neotropical savanna. Arthropod Plant Interact. 7, 191-199.

Chuine, I., Beaubien, E.G., 2001. Phenology is a major determinant of tree species range. Ecol. Lett. 4, 500-510.

Colomina, I., Molina, P., 2014. Unmanned aerial systems for photogrammetry and remote sensing: a review. ISPRS J. Photogramm. Remote Sens. 92, 79-97.

Crimmins, M.A., Crimmins, T.M., 2008. Monitoring plant phenology using digital repeat photography. Environ. Manag. 41, 949-958.

Cruz-Neto, O., Machado, I.C., Duarte Jr., J.A., Lopes, A.V., 2011. Synchronous phenology of hawkmoths (Sphingidae) and Inga species (Fabaceae-Mimosoideae): implications for the restoration of the Atlantic forest of northeastern Brazil. Biodivers. Conserv. 20, 751-765.

D'Antonio, C.M., 2000. Fire, plant invasions, and global changes. In: Mooney, H.A., Hobbs, R.J. (Eds.), Invasives Species in a Changing World. Island Press, Washington, DC, pp. 65-93.

Datta, A., Rane, A., 2013. Phenology, seed dispersal and regeneration patterns of Horsfieldia kingii, a rare wild nutmeg. Trop. Conserv. Sci. 6, 674-689.

de Melo, F.P.L., Dirzo, R., Tabarelli, M., 2006. Biased seed rain in forest edges: evidence from the Brazilian Atlantic forest. Biol. Conserv. 132, 50-60.

D'Eon, R.G., Glenn, S.M., Parfitt, I., Fortin, M.-J., 2002. Landscape connectivity as a function of scale and organism vagility in a real forested landscape. Conserv. Ecol. 6, 10 .

Develey, P.F., Peres, C.A., 2000. Resource seasonality and the structure of mixed species bird flocks in a coastal Atlantic forest of southeastern Brazil. J. Trop. Ecol. 16, 33-53.

Diaz-Martin, Z., Swamy, V., Terborgh, J., Alvarez-Loayza, P., Cornejo, F., 2014. Identifying keystone plant resources in an Amazonian forest using a long-term fruit-fall record. J. Trop. Ecol. 30, 291-301.

Diez, J.M., Ibáñez, I., Miller-Rushing, A.J., Mazer, S.J., Crimmins, T.M., Crimmins, M.A Bertelsen, C.D., Inouye, D.W., 2012. Forecasting phenology: from species variability to community patterns. Ecol. Lett. 15, 545-553.

Dirzo, R., Young, H.S., Galetti, M., Ceballos, G., Isaac, N.J.B., Collen, B., 2014. Defaunation in the Anthropocene. Science 345, 401-406.

Donnelly, A., Caffarra, A., O'Neill, B., 2011. A review of climate-driven mismatches between interdependent phenophases in terrestrial and aquatic ecosystems. Int J. Biometeorol. 55, 805-817.

Dupont, Y.L., Padrón, B., Olesen, J.M., Petanidou, T., 2009. Spatio-temporal variation in the structure of pollination networks. Oikos 118, 1261-1269.

Encinas-Viso, F., Revilla, T.A., Etienne, R.S., 2012. Phenology drives mutualistic network structure and diversity. Ecol. Lett. 15, 198-208.

Eriksson, O., Bolmgren, K., Westin, A., Lennartsson, T., 2015. Historic hay cutting dates from Sweden 1873-1951 and their implications for conservation management of species-rich meadows. Biol. Conserv. 184, 100-107.

Estiarte, M., Peñuelas, J., 2015. Alteration of the phenology of leaf senescence and fall in winter deciduous species by climate change: effects on nutrient proficiency. Glob. Chang. Biol. 21, 1005-1017.

Fahrig L., Baudry, J., Brotons, L., Burel, F.G., Crist, T.O., Fuller, RJ., Sirami, C, Siriwardena, G.M., Martin, J.L., 2011. Functional landscape heterogeneity and animal biodiversity in agricultural landscapes. Ecol. Lett. 14, 101-112.

Frankie, G.W., Baker, H.G., Opler, P.A., 1974. Comparative phenological studies of trees in tropical wet and dry forests in the lowlands of Costa Rica. J. Ecol. 62, 881-919.

Fuccillo, K.K., Crimmins, T.M., de Rivera, C.E., Elder, T.S., 2014. Assessing accuracy in citizen science-based plant phenology monitoring. Int. J. Biometeorol. 1-10.

Gaira, K.S., Dhar, U., Belwal, O.K., 2011. Potential of herbarium records to sequence phenological pattern: a case study of Aconitum heterophyllum in the Himalaya. Biodivers. Conserv. 20, 2201-2210.

Galetti, M., Dirzo, R., 2013. Ecological and evolutionary consequences of living in a defaunated world. Biol Conserv, 163, 1-6.

Galetti, M., Guevara, R., Cortes, M.C., Fadini, R., Von Matter, S., Leite, A.B., Labecca, F., Ribeiro, T., Carvalho, C.S., Collevatti, R.G., Pires, M.S.M., Guimaraes Jr., P.R., Brancalion, P.H., Ribeiro, M.C., Jordano, P., 2013. Functional extinction of birds drives rapid evolutionary changes in seed size. Science 340, 1086-1090.

Garibaldi, L.A., Steffan-Dewenter, I., Winfree, R., Aizen, M.A., Bommarco, R., Cunningham, S.A., Kremen, C., Carvalheiro, L.G., Harder, L.D., Afik, O., Bartomeus, I., Benjamin, F. Boreux, V., Cariveau, D., Chacoff, N.P., Dudenhöffer, J.H., Freitas, B.M., Ghazoul, J., Greenleaf, S., Hipólito, J., Holzschuh, A., Howlett, B., Isaacs, R., Javorek, S.K., Kennedy, C.M., Krewenka, K.M., Krishnan, S., Mandelik, Y., Mayfield, M.M., Motzke I., Munyuli, T., Nault, B.A., Otieno, M., Petersen, J., Pisanty, G., Potts, S.G., Rader, R. Ricketts, T.H., Rundlöf, M., Seymour, C.L., Schüepp, C., Szentgyörgyi, H., Taki, H., Tscharntke, T., Vergara, C.H., Viana, B.F., Wanger, T.C., Westphal, C., Williams, N., Klein, A.M., 2013. Wild pollinators enhance fruit set of crops regardless of honey bee abundance. Science 339, 1608-1611.

Garwood, N.C., 1983. Seed germination in a seasonal tropical forest in Panama: a community study. Ecology 53, 159-181.

GCOS, 2010. Implementation Plan for the Global Observing System for Climate in Support of the UNFCCC (2010 Update). World Meteorological Organization, Geneva. 
Gonsamo, A., Chen, J.M., Wu, C., 2013. Citizen Science: linking the recent rapid advances of plant flowering in Canada with climate variability. Sci. Rep. 3.

Graham, E.A., Henderson, S., Schloss, A., 2011. Using mobile phones to engage citizen scientists in research. EOS Trans. Am. Geophys. Union 92, 313-315.

Hagen, M., Kissling, W.D., Rasmussen, C., De Aguiar, M.A.M., Brown, L.E., Carstensen, D.W., Alves-Dos-Santos, I., Dupont, Y.L., Edwards, F.K., Genini, J., Guimarães Jr., P.R., Jenkins, G.B., Jordano, P., Kaiser-Bunbury, C.N., Ledger, M.E., Maia, K.P., Marquitti, F.M.D. McLaughlin, Ã.r., Morellato, L.P.C., O'Gorman, E.J., Trøjelsgaard, K., Tylianakis, J.M. Vidal, M.M., Woodward, G., Olesen, J.M., Ute, J., Guy, W., 2012. Biodiversity, species interactions and ecological networks in a fragmented world. Adv. Ecol. Res. 46, 89-210.

Hanya, G., Chapman, C.A., 2013. Linking feeding ecology and population abundance: a review of food resource limitation on primates. Ecol. Res. 28, 183-190.

Hart, R., Salick, J., Ranjitkar, S., Xu, J.C., 2014. Herbarium specimens show contrasting phenological responses to Himalayan climate. Proc. Natl. Acad. Sci. U. S. A. 111, 10615-10619.

Haugaasen, T., Peres, C.A., 2007. Vertebrate responses to fruit production in Amazonian flooded and unflooded forests. Biodivers. Conserv. 16, 4165-4190.

Hawes, J.E., Peres, C.A., 2014. Ecological correlates of trophic status and frugivory in neotropical primates. Oikos 123, 365-377.

Hegland, S.J., Nielsen, A., Lázaro, A., Bjerknes, A.-L., Totland, Ø., 2009. How does climate warming affect plant-pollinator interactions? Ecol. Lett. 12, 184-195.

Herrera, C.M., 2009. Multiplicity in Unity: Plant Subindividual Variation \& Interactions with Animals. The University Of Chicago Press, Chicago.

Hindle, B.J., Kerr, C.L., Richards, S.A., Willis, S.G., 2015. Topographical variation reduces phenological mismatch between a butterfly and its nectar source. J. Insect Conserv. 19, 227-236.

Hoffmann, W.A., 1998. Post-burn reproduction of woody plants in a neotropical savanna: the relative importance of sexual and vegetative reproduction. J. Appl. Ecol. 35, 422-433.

Hoye, T.T., Post, E., Schmidt, N.M., Trojelsgaard, K., Forchhammer, M.C., 2013. Shorter flowering seasons and declining abundance of flower visitors in a warmer Arctic. Nat. Clim. Chang. 3, 759-763.

Huxel, G.R., 1999. Rapid displacement of native species by invasive species: effects of hybridization. Biol. Conserv. 89, 143-152.

IPCC, 2014. Climate Change 2014: Impacts, Adaptation, and Vulnerability. Part A: Globa and Sectoral Aspects. Contribution of Working Group II to the Fifth Assessment Report of the Intergovernmental Panel on Climate Change. Cambridge University Press, Cambridge, United Kingdom and New York, NY, USA

Jerozolimski, A., Peres, C.A., 2003. Bringing home the biggest bacon: a cross-site analysis of the structure of hunter-kill profiles in Neotropical forests. Biol. Conserv. 111, 415-425.

Kaiser-Bunbury, C.N., Muff, S., Memmott, J., Müller, C.B., Caflisch, A., 2010. The robustness of pollination networks to the loss of species and interactions: a quantitative approach incorporating pollinator behaviour. Ecol. Lett. 13, 442-452.

Kannan, R., James, D.A., 1999. Fruiting phenology and the conservation of the great pied hornbill (Buceros bicornis) in the western Ghats of southern India. Biotropica 31, 167-177.

Kochmer, J.P., Handel, S.N., 1986. Constraints and competition in the evolution of flowering phenology. Ecol. Monogr. 56, 303-325.

Kocsis, M., Hufnagel, L., 2011. Impacts of climate change on Lepidoptera species and communities. Appl. Ecol. Environ. Res. 9, 43-72.

Koh, L.P., Wich, S.A., 2012. Dawn of drone ecology: low-cost autonomous aerial vehicles for conservation. Trop. Conserv. Sci. 5, 121-132.

Kudo, G., Ida, T.Y., 2013. Early onset of spring increases the phenological mismatch between plants and pollinators. Ecology 94, 2311-2320.

Lamarre, G.P.A., Mendoza, I., Fine, P.V.A., Baraloto, C., 2014. Leaf synchrony and insect herbivory among tropical tree habitat specialists. Plant Ecol. 215, 209-220.

Laurance, W.F., 2008. Theory meets reality: how habitat fragmentation research has transcended island biogeographic theory. Biol. Conserv. 141, 1731-1744.

Lavoie, C., Lachance, D., 2006. A new herbarium-based method for reconstructing the phenology of plant species across large areas. Am. J. Bot. 93, 512-516.

Lisi, C.S., Tomazello, M., Botosso, P.C., Roig, F.A., Maria, V.R.B., Ferreira-Fedele, L., Voigt A.R.A., 2008. Tree-ring formation, radial increment periodicity, and phenology of tree species from a seasonal semi-deciduous forest in southeast Brazil. IAWA Bull. 29, 189-207.

Marushia, R.G., Cadotte, M.W., Holt, J.S., 2010. Phenology as a basis for management of exotic annual plants in desert invasions. J. Appl. Ecol. 47, 1290-1299.

Memmott, J., Craze, P.G., Waser, N.M., Price, M.V., 2007. Global warming and the disruption of plant-pollinator interactions. Ecol. Lett. 10, 710-717.

Mendoza, I., Peres, C.A., Morellato, L.P.C., 2014. Large-scale patterns of fruiting seasonality across the Neotropics. EGU General Assembly Conference Abstracts, p. 11840 .

Menzel, A., Sparks, T.H., Estrella, N., Koch, E., Aasa, A., Ahas, R., Alm-Kuebler, K., Bissolli, P., Braslavska, O.g., Briede, A., Chmielewski, F.M., Crepinsek, Z., Curnel, Y., Dahl, A., Defila, C., Donnelly, A., Filella, Y., Jatcza, K., Mage, F., Mestre, A., Nordli, O., Penuelas, J. Pirinen, P., Remisova, V., Scheifinger, H., Striz, M., Susnik, A., Van Vliet, A.J.H. Wielgolaski, F.-E., Zach, S., Zust, A., 2006. European phenological response to climate change matches the warming pattern. Glob. Chang. Biol. 12, 1969-1976.

Miller-Rushing, A.J., Weltzin, J., 2009. Phenology as a tool to link ecology and sustainable decision making in a dynamic environment. New Phytol. 184, 743-745.

Morales, C.L., Traveset, A., 2009. A meta-analysis of impacts of alien vs. native plants on pollinator visitation and reproductive success of co-flowering native plants. Ecol. Lett. 12, 716-728.

Morellato, L.P.C., Leitão-Filho, H., 1996. Reproductive phenology of climbers in a Southeastern Brazilian forest. Biotropica 28, 180-191.
Morellato, L.P.C., Alberton, B., Almeida, J., Alex, J., Mariano, G., Torres, R., 2014. e-Phenology: monitoring leaf phenology and tracking climate changes in the tropics. EGU General Assembly Conference Abstracts, p. 12020.

Morellato, L.P.C., Camargo, M.G.G., Gressler, E., 2013. A review of plant phenology in South and Central America. In: Schwartz, M.D. (Ed.), Phenology: An Integrative Environmental Science. Springer, The Neederlands, pp. 91-113.

Morellato, L.P.C., Talora, D.C., Takahasi, A., Bencke, C.C., Romera, E.C., Zipparro, V.B., 2000. Phenology of Atlantic rain forest trees: a comparative study. Biotropica $32,811-823$.

Morisette, J.T., Richardson, A.D., Knapp, A.K., Fisher, J.I., Graham, E.A., Abatzoglou, J., Wilson, B.E., Breshears, D.D., Henebry, G.M., Hanes, J.M., Liang, L., 2009. Tracking the rhythm of the seasons in the face of global change: phenological research in the 21 st century. Front. Ecol. Environ. 7, 253-260.

Nagendra, H., Lucas, R., Honrado, J.P., Jongman, R.H., Tarantino, C., Adamo, M., Mairota, P., 2013. Remote sensing for conservation monitoring: assessing protected areas, habitat extent, habitat condition, species diversity, and threats. Ecol. Indic. 33, 45-59.

Novotny, V., Drozd, P., Miller, S.E., Kulfan, M., Janda, M., Basset, Y., Weiblen, G.D., 2006. Why are there so many species of herbivorous insects in tropical rainforests? Science 313, 1115-1118.

Olesen, J.M., Bascompte, J., Elberling, H., Jordano, P., 2008. Temporal dynamics in a pollination network. Ecology 89, 1573-1582.

Ollerton, J., Winfree, R., Tarrant, S., 2011. How many flowering plants are pollinated by animals? Oikos 120, 321-326.

Packard, S., Mutel, C.F., Jordan, W.F., 2005. The Tallgrass Restoration Handbook: For Prairies, Savannas and Woodlands. 2nd New edition. Island Press, Washington DC.

Paneque-Gálvez, J., McCall, M.K., Napoletano, B.M., Wich, S.A., Koh, L.P., 2014. Small drones for community-based forest monitoring: an assessment of their feasibility and potential in tropical areas. Forests 5, 1481-1507.

Paritsis, J., Raffaele, E., Veblen, T.T., 2006. Vegetation disturbance by fire affects plant reproductive phenology in a shrubland community in northwestern Patagonia, Argentina. N. Z. J. Ecol. 30, 387-395.

Pausas, J.G., Bradstock, R.A., Keith, D.A., Keeley, J.E., 2004. Plant functional traits in relation to fire in crown-fire ecosystems. Ecology 85, 1085-1100.

Pereira, H.M., Ferrier, S., Walters, M., Geller, G.N., Jongman, R.H.G., Scholes, R.J., Bruford, M.W., Brummitt, N., Butchart, S.H.M., Cardoso, A.C., Coops, N.C., Dulloo, E., Faith, D.P., Freyhof, J., Gregory, R.D., Heip, C., Höft, R., Hurtt, G., Jetz, W., Karp, D.S., McGeoch, M.A., Obura, D., Onoda, Y., Pettorelli, N., Reyers, B., Sayre, R., Scharlemann, J.P.W., Stuart, S.N., Turak, E., Walpole, M., Wegmann, M., 2013. Essential biodiversity variables. Science 339, 277-278.

Peres, C.A., 1994a. Composition, density, and fruiting phenology of arborescent palms in an Amazonian terra firme forest. Biotropica 285-294.

Peres, C.A., 1994b. Primate responses to phenological changes in an Amazonian terra firme forest. Biotropica 98-112.

Peres, C.A., 2000. Identifying keystone plant resources in tropical forests: the case of gums from Parkia pods. J. Trop. Ecol. 16, 287-317.

Peres, C.A., Baider, C., Zuidema, P.A., Wadt, L.H., Kainer, K.A., Gomes-Silva, D.A., Salomão, R.P., Simões, L.L., Franciosi, E.R., Valverde, F.C., 2003. Demographic threats to the sustainability of Brazil nut exploitation. Science 302, 2112-2114.

Petanidou, T., Kallimanis, A.S., Sgardelis, S.P., Mazaris, A.D., Pantis, J.D., Waser, N.M., 2014. Variable flowering phenology and pollinator use in a community suggest future phenological mismatch. Acta Oecol. 59, 104-111.

Phillips, O.L., Martinez, R.V., Arroyo, L., Baker, T.R., Killeen, T., Lewis, S.L., Malhi, Y., Mendoza, A.M., Neill, D., Vargas, P.N., Alexiades, M., Ceron, C., DiFiore, A., Erwin, T. Jardim, A., Palacios, W., Saldias, M., Vinceti, B., 2002. Increasing dominance of large lianas in Amazonian forests. Nature 418, 770-774.

Polgar, C.A., Primack, R.B., 2011. Leaf-out phenology of temperate woody plants: from trees to ecosystems. New Phytol. 191, 926-941.

Post, E., Pedersen, C., Wilmers, C.C., Forchhammer, M.C., 2008. Warming, plant phenology and the spatial dimension of trophic mismatch for large herbivores. Proc. R. Soc. B Biol. Sci. 275, 2005-2013.

Primack, D., Imbres, C., Primack, R.B., Miller-Rushing, A.J., Del Tredici, P., 2004. Herbarium specimens demonstrate earlier flowering times in response to warming in Boston. Am. J. Bot. 91, 1260-1264.

Primack, R., 2014. Walden Warming - Climate Change Comes to Thoreau's Woods. The University of Chicago Press, Chicago.

Pritchard, H.W., Daws, M.I., Fletcher, B.J., Gaméné, C.S., Msanga, H.P., Omondi, W., 2004. Ecological correlates of seed desiccation tolerance in tropical African dryland trees. Am. J. Bot. 91, 863-870.

Proença, C.E., Filer, D.L., Lenza, E., Silva, J.S., Harris, S.A., 2012. Phenological Predictability Index in BRAHMS: a tool for herbarium-based phenological studies. Ecography 35, 289-293.

Quesada, M., Stoner, K.E., Lobo, J.A., Herrerias-Diego, Y., Palacios-Guevara, C., MunguiaRosas, M.A., Salazar, K.A.O., Rosas-Guerrero, V., 2004. Effects of forest fragmentation on pollinator activity and consequences for plant reproductive success and mating patterns in bat-pollinated bombacaceous trees. Biotropica 36, 131-138.

Rafferty, N.E., Ives, A.R., 2012. Pollinator effectiveness varies with experimental shifts in flowering time. Ecology 93, 803-814.

Rawal, D.S., Kasel, S., Keatley, M.R., Nitschke, C.R. 2015. Herbarium records identify sensitivity of flowering phenology of eucalypts to climate: implications for species response to climate change. Austral Ecol. 40, 117-125.

Reed, B.C., Schwartz, M.D., Xiao, X., 2013. Remote sensing phenology: status and the way forward. In: Schwartz, M.D. (Ed.), Phenology: An Integrative Environmental Science. Springer, Netherlands, pp. 91-113

Richardson, A.D., Braswell, B.H., Hollinger, D.Y., Jenkins, J.P., Ollinger, S.V., 2009. Nearsurface remote sensing of spatial and temporal variation in canopy phenology. Ecol. Appl. 19, 1417-1428. 
Richardson, A.D., Keenan, T.F., Migliavacca, M., Ryu, Y., Sonnentag, O., Toomey, M., 2013. Climate change, phenology, and phenological control of vegetation feedbacks to the climate system. Agric. For. Meteorol. 169, 156-173.

Richardson, D.M., Pyšek, P., Rejmánek, M., Barbour, M.G., Panetta, F.D., West, C.J., 2000. Naturalization and invasion of alien plants: concepts and definitions. Divers. Distrib. 6, 93-107.

Rivera, G., Borchert, R., 2001. Induction of flowering in tropical trees by a 30-min reduction in photoperiod: evidence from field observations and herbarium specimens. Tree Physiol. 21, 201-212.

Roig, F.A., 2000. Dendrocronología en los bosques del Neotropico: revisión y prospección futura. In: Roig, F.A. (Ed.), Dendrocronología en América Latina. EDIUNC, Mendoza, pp. 307-355.

Rosas-Guerrero, V., Aguilar, R., Martén-Rodríguez, S., Ashworth, L., Lopezaraiza-Mikel, M., Bastida, J.M., Quesada, M., 2014. A quantitative review of pollination syndromes: do floral traits predict effective pollinators? Ecol. Lett. 17, 388-400.

Rosemartin, A.H., Crimmins, T.M., Enquist, C.A.F., Gerst, K.L., Kellermann, J.L., Posthumus, E.E., Denny, E.G., Guertin, P., Marsh, L., Weltzin, J.F., 2014. Organizing phenological data resources to inform natural resource conservation. Biol. Conserv. 173, 90-97.

Rosenzweig, C., Karoly, D., Vicarelli, M., Neofotis, P., Wu, Q., Casassa, G., Menzel, A., Root, T.L., Estrella, N., Seguin, B., Tryjanowski, P., Liu, C., Rawlins, S., Imeson, A., 2008. Attributing physical and biological impacts to anthropogenic climate change. Nature 453 , 353-357.

Rossi, S., Anfodillo, T., Čufar, K., Cuny, H.E., Deslauriers, A., Fonti, P., Frank, D., Gričar, J. Gruber, A., King, G.M., 2013. A meta-analysis of cambium phenology and growth: linear and non-linear patterns in conifers of the northern hemisphere. Ann. Bot. 112, 1911-1920.

Rossi, S., Morin, H., Deslauriers, A., 2012. Causes and correlations in cambium phenology: towards an integrated framework of xylogenesis. J. Exp. Bot. 63, 2117-2126.

Salazar, A., Goldstein, G., Franco, A.C., Miralles-Wilhelm, F., 2011. Timing of seed dispersal and dormancy, rather than persistent soil seed-banks, control seedling recruitment of woody plants in Neotropical savannas. Seed Sci. Res. 21, 103-116.

Satake, A., Kawagoe, T., Saburi, Y., Chiba, Y., Sakurai, G., Kudoh, H., 2013. Forecasting flowering phenology under climate warming by modelling the regulatory dynamics of flowering-time genes. Nat. Commun. 4.

Schellhorn, N.A., Gagic, V., Bommarco, R., 2015. Time will tell: resource continuity bolsters ecosystem services. Trends Ecol. Evol. 30, 524-530.

Schmidt, I.B., Figueiredo, I.B., Scariot, A., 2007. Ethnobotany and effects of harvesting on the population ecology of Syngonanthus nitens (Bong.) Ruhland (Eriocaulaceae), a NTFP from Jalapão Region, central Brazil. Econ. Bot. 61, 73-85.

Schnitzer, S.A., van der Heijden, G., Mascaro, J., Carson, W.P., 2014. Lianas in gaps reduce carbon accumulation in a tropical forest. Ecology 95, 3008-3017.

Schöngart, J., 2008. Growth-Oriented Logging (GOL): a new concept towards sustainable forest management in Central Amazonian varzea floodplains. For. Ecol. Manag. 256, 46-58.

Schöngart, J., Arieira, J., Felfili Fortes, C., Cezarine de Arruda, E., Nunes da Cunha, C., 2011. Age-related and stand-wise estimates of carbon stocks and sequestration in the aboveground coarse wood biomass of wetland forests in the northern Pantanal, Brazil. Biogeosciences 8, 3407-3421.

Schöngart, J., Gribel, R., Ferreira da Fonseca-Junior, S., Haugaasen, T., 2015. Age and growth patterns of Brazil nut trees (Bertholletia excelsa bonpl.) in Amazonia, Brazil. Biotropica 47, 550-558

Schupp, E.W., Jordano, P., Gomez, J.M., 2010. Seed dispersal effectiveness revisited: a conceptual review. New Phytol. 188, 333-353.

Schwartz, M.D., Ahas, R., Aasa, A., 2006. Onset of spring starting earlier across the northern hemisphere. Glob. Chang. Biol. 12, 343-351.

Schweingruber, F.H., 1996. Dendrochronology - an extremely exact measuring tool for the study of environmental and human history. Naturwissenschaften 83, 370-377.

Staggemeier, V.G., Diniz-Filho, J.A.F., Morellato, L.P.C., 2010. The shared influence of phylogeny and ecology on the reproductive patterns of Myrteae (Myrtaceae). J. Ecol. 98, 1409-1421.
Staggemeier, V.G., Diniz-Filho, J.A.F., Zipparro, V.B., Gressler, E., de Castro, E.R., Mazine, F, da Costa, I.R., Lucas, E., Morellato, L.P.C., 2015. Clade-specific responses regulate phenological patterns in Neotropical Myrtaceae. Perspect. Plant Ecol. 17, 476-490.

Tannus, J.L.S., Assis, M.A., 2004. Composição de espécies vasculares de campo sujo e campo úmido em área de cerrado, Itirapina - SP, Brasil. Rev. Bras. Bot. 27, 489-506.

Thébault, E., Fontaine, C., 2010. Stability of ecological communities and the architecture of mutualistic and trophic networks. Science 329, 853-856.

Theobald, E.J., Ettinger, A.K., Burgess, H.K., DeBey, L.B., Schmidt, N.R., Froehlich, H.E. Wagner, C., HilleRisLambers, J., Tewksbury, J., Harsch, M.A., Parrish, J.K., 2015. Global change and local solutions: tapping the unrealized potential of citizen science for biodiversity research. Biol. Conserv. 181, 236-244.

Thomson, L.J., Macfadyen, S., Hoffmann, A.A., 2010. Predicting the effects of climate change on natural enemies of agricultural pests. Biol. Control 52, 296-306.

van Asch, M., Visser, M.E., 2007. Phenology of forest caterpillars and their host trees: the importance of synchrony. Annual Review of Entomology, pp. 37-55.

van der Sleen, P., Groenendijk, P., Vlam, M., Anten, N.P.R., Boom, A., Bongers, F., Pons, T.L., Terburg, G., Zuidema, P.A., 2015. No growth stimulation of tropical trees by 150 years of $\mathrm{CO}_{2}$ fertilization but water-use efficiency increased. Nat. Geosci. 8, 24-28.

Vázquez, D.P., Bluthgen, N., Cagnolo, L., Chacoff, N.P., 2009. Uniting pattern and process in plant-animal mutualistic networks: a review. Ann. Bot. 103, 1445-1457.

Vilà, M., Espinar, J.L., Hejda, M., Hulme, P.E., Jarošík, V., Maron, J.L., Pergl, J., Schaffner, U, Sun, Y., Pyšek, P., 2011. Ecological impacts of invasive alien plants: a meta-analysis of their effects on species, communities and ecosystems. Ecol. Lett. 14, 702-708.

Vilà, M., Weber, E., Antonio, C.D., 2000. Conservation implications of invasion by plant hybridization. Biol. Invasions 2, 207-217.

Weinig, C., Ewers, B.E., Welch, S.M., 2014. Ecological genomics and process modeling of local adaptation to climate. Curr. Opin. Plant Biol. 18, 66-72.

Williams, P.R., Congdon, R.A., Grice, A.C., Clarke, P.J., 2005. Germinable soil seed banks in a tropical savanna: seasonal dynamics and effects of fire. Austral Ecol. 30, 79-90.

Willis, C.G., Ruhfel, B., Primack, R.B., Miller-Rushing, A.J., Davis, C.C., 2008. Phylogenetic patterns of species loss in Thoreau's woods are driven by climate change. Proc. Natl. Acad. Sci. 105, 17029-17033.

Willis, K.S., 2015. Remote sensing change detection for ecological monitoring in United States protected areas. Biol. Conserv. 182, 233-242.

Wolkovich, E.M., Cleland, E.E., 2011. The phenology of plant invasions: a community ecology perspective. Front. Ecol. Environ. 9, 287-294.

Wolkovich, E.M., Cook, B.I., Davies, T.J., 2014. Progress towards an interdisciplinary science of plant phenology: building predictions across space, time and species diversity. New Phytol. 201, 1156-1162.

Worbes, M., 2002. One hundred years of tree-ring research in the tropics-a brief history and an outlook to future challenges. Dendrochronologia 20, 217-231.

Wright, S.J., Calderon, O., 2006. Seasonal, El Niño and longer term changes in flower and seed production in a moist tropical forest. Ecol. Lett. 9, 35-44.

Wright, S.J., Carrasco, C., Calderon, O., Paton, S., 1999. The El Niño Southern Oscillation variable fruit production, and famine in a tropical forest. Ecology 80, 1632-1647.

Yang, W., Liu, F., Zhang, S., An, S., 2013. Dispersal and germination syndromes of tree seeds in a seasonal evergreen monsoon rainforest on Hainan Island, China. Seed Sci. Res. 23, 41-55.

Zahawi, R.A., Dandois, J.P., Holl, K.D., Nadwodny, D., Reid, J.L., Ellis, E.C., 2015. Using lightweight unmanned aerial vehicles to monitor tropical forest recovery. Biol. Conserv. 186, 287-295

Zalamea, P.-C., Munoz, F.o., Stevenson, P.R., Paine, C.E.T., Sarmiento, C., Sabatier, D., Heuret P., 2011. Continental-scale patterns of Cecropia reproductive phenology: evidence from herbarium specimens. Proc. R. Soc. Lond. B Biol. Sci. 